\title{
An Investigation into Art Therapy Aided Health and Well-Being Research: A 75-Year Bibliometric Analysis
}

\author{
Zhen Liu ${ }^{1}{ }^{\mathbb{D}}$, Zulan Yang ${ }^{1, *}$, Chang Xiao ${ }^{1}$, Ke Zhang ${ }^{1}$ and Mohamed Osmani ${ }^{2}$ \\ 1 School of Design, South China University of Technology, Guangzhou 510006, China; \\ liuzjames@scut.edu.cn (Z.L.); xiaocsd@scut.edu.cn (C.X.); kezh@scut.edu.cn (K.Z.) \\ 2 School of Architecture, Building and Civil Engineering, Loughborough University, \\ Loughborough LE11 3TU, UK; m.osmani@lboro.ac.uk \\ * Correspondence: 201921052616@mail.scut.edu.cn
}

Citation: Liu, Z.; Yang, Z.; Xiao, C.; Zhang, K.; Osmani, M. An Investigation into Art Therapy Aided Health and Well-Being Research: A 75-Year Bibliometric Analysis. Int. J. Environ. Res. Public Health 2022, 19, 232. https://doi.org/10.3390/ ijerph19010232

Academic Editor:

Paul B. Tchounwou

Received: 19 November 2021

Accepted: 23 December 2021

Published: 26 December 2021

Publisher's Note: MDPI stays neutral with regard to jurisdictional claims in published maps and institutional affiliations.

Copyright: (c) 2021 by the authors. Licensee MDPI, Basel, Switzerland. This article is an open access article distributed under the terms and conditions of the Creative Commons Attribution (CC BY) license (https:// creativecommons.org/licenses/by/ $4.0 /)$.

\begin{abstract}
Considering the physical, and psychological impacts and challenges brought about the coronavirus disease 2019 (COVID-19), art therapy (AT) provides opportunities to promote human health and well-being. There are few systematic analysis studies in the fields of AT, which can provide content and direction for the potential value and impact of AT. Therefore, this paper aims to critically analyze the published work in the field of AT from the perspective of promoting health and well-being, and provides insights into current research status, hotspots, limitations, and future development trends of AT. This paper adopts a mixed method of quantitative and qualitative analysis including bibliometric analysis and keyword co-occurrence analysis. The results indicate that: (1) the current studies on AT are mostly related to research and therapeutic methods, types of AT, research populations and diseases, and evaluation of therapeutic effect of AT. The research method of AT mainly adopts qualitative research, among which creative arts therapy and group AT are common types of AT, and its main research populations are children, veterans, and adolescents. AT-aided diseases are trauma, depression, psychosis, dementia, and cancer. In addition, the therapeutic methods are mainly related to psychotherapy, drama, music, and dance/movement. Further, computer systems are an important evaluation tool in the research of AT; (2) the future development trend of AT-aided health and well-being based on research hotspots, could be focused on children, schizophrenia, well-being, mental health, palliative care, veterans, and the elderly within the context of addressing COVID-19 challenges; and (3) future AT-aided health and well-being could pay more attention to innovate and integrate the therapeutic methods of behavior, movement, and technology, such as virtual reality and remote supervision.
\end{abstract}

Keywords: art therapy; bibliometric analysis; co-occurrence analysis; health and well-being; therapeutic method; children; adolescent; elderly; psychotherapy; virtual reality

\section{Introduction}

In December 2019, a novel coronavirus disease 2019 (COVID-19) broke out in Wuhan, China. With the rapid spread of the new crown virus, the World Health Organization (WHO) declared the COVID-19 epidemic as a public health emergency of international concern on 30 January 2020 [1]. The spread of the COVID-19 across countries globally has brought unprecedented challenges to all walks of life, such as the international public health, trade, economic, and education systems, which influence the well-being of human society [2]. In addition, the COVID-19 has negatively affected the global service and manufacturing industry [3], and caused commercial stagnation, especially in the tourism, hotel, education, retail, and health sectors [4]. Further, in order to overcome this global threat, the Centers for Disease Control and Prevention of the WHO proposes to adopt preventive measures, such as social distancing, washing hands, and wearing masks, and isolation policy to reduce the spread of the COVID-19 [5]. However, the isolation policy that restricts people's movement not only has a significant impact on the economy, environment, and 
society [6], but also increases the symptoms of people's post-traumatic stress disorder (PTSD) and feelings of confusion, loneliness, boredom, and anger in the psychological field [7]. For example, under the influence of the epidemic, some children and adolescents have developed anxiety, depression, sleep and appetite disorders, and social difficulties [8], and the elderly become lonelier and more fearful [9]. In short, faced with the sudden COVID-19 and respective confinements and lockdowns, not only have society and the economy been affected, but for people across the world, noticeable impacts on people's mental and physical health have been created. Mental health includes emotional, psychological, and social well-being, such as anxiety, life pressure, depression, and suicide. Hence, therapy methods provide mental health patients with tools to identify and solve problems that arise from life stressors.

Among the many non-drug treatments, art therapy (AT) is a comprehensive treatment that uses psychotherapy [10] and artistic creation processes [11], such as drama, music, dance movements, and drawing to promote health and well-being. In addition, AT is a non-verbal intervention [12-14], which can aid mental disorders affecting people across all ages through the intermediary of art $[15,16]$. AT, as an expression therapy, can bring many benefits, such as encouraging communication and expressing emotions [17], promoting emotional catharsis and experiencing positive emotions [18], increasing positive behaviors [19], and improving the quality of life of patients [20-22] and their self-esteem [23-25]. The art creation process of AT provides a medium through which different realities, attitudes, and feelings can be expressed, examined, and tried [26]. It enables individuals to use art to express themselves creatively [27]. Thus, AT plays a positive role in alleviating many mental and physical health conditions, such as depression [28-30], psychosis [31-33], PTSD [34-36], dementia [19,37,38], cancer [39-41], and diabetes [42-44].

AT is a valuable way of expression, and art shows a great promise in the direction of a sustainable future [45]. Art-based methods and aesthetics generate emotional connections in many fields, such as healthcare, which can bring sustainable value and results to individuals, organizations, and collectives [46]. In addition, the study of AT has potential value in solving the ongoing impact of the post-COVID-19 era [47,48]. In general, AT is an effective intervention to promote health in the context of the COVID-19 epidemic, and the use of art presents a potential link with social sustainable development. However, the most of systematic analysis of AT-aided health and well-being studies are focused on specific fields, such as AT interventions for cancer patients [49], AT support for people with psychosis [27], AT assistance for traumatized children [50,51], and visual AT for cognitive and psychological symptoms in the elderly [52], which provide only partial information of value for understanding the content structure and research hotspots of the field of AT-aided health and well-being studies. Therefore, the aim of this paper is to analyze the current research status, research hotspots, research deficiencies, and future development trends of AT-aided studies from the perspective of promoting health and well-being.

\section{Methods}

This paper adopts a mixed research method, which comprises a bibliometric analysis to quantitatively examine AT-aided health and well-being, identifying significant research structure and research topics, and a follow-up qualitative review to reveal the content of different AT research themes. In the quantitative data analysis, histograms, pie charts, and visual maps of keyword co-occurrence analysis in VOSviewer are used to analyze the current research status and research hotspots of AT. Bibliometric analysis is widely used to analyze the published literature in a particular field, which helps to evaluate the trend of research activities over time [53]. Although, due to the complexity of scientific development, the use of bibliometrics can only be a very rough measure of the law of scientific development, it can reveal the statistical association between keywords and trend topics [54]. Keywords can represent the core theme of article content [55]. According to the co-occurrence analysis of the frequency of keywords appearing in article, a brief cluster analysis can be performed [56], which can reveal statistical connections between 
individual topics [57]. In addition, VOSviewer is a free software tool that can be used to create and visualize bibliometric maps of scientific publications, authors, journals, countries, institutions, and keywords [58]. In the review articles related to AT, the research methods greatly include scope review [59], integrative review [60,61], meta-analysis [62,63], and quantitative analysis [64]. Further, there is a lack of research that use the visualization of keyword co-occurrence analysis to summarize the categories and research hotspots of AT-aided health and well-being. Therefore, this paper uses visual maps of keyword cooccurrence analysis in VOSviewer to summarize the theme category and research hotspots of AT-aided health and well-being, and summarizes the actual application of AT-aided health and well-being on the basis of bibliometric analysis.

ScienceDirect [65] is the full-text database platform of Elsevier, the world's leading publishing company, and the world's largest full-text electronic resource database for science, technology, and medicine. The resources on the ScienceDirect platform have established a broad, credible, high-quality interdisciplinary research and academic literature foundation from the four disciplines of physical sciences and engineering, life sciences, health sciences, social sciences, and humanities, which can help reveal the answers to the most urgent problems in the world. Therefore, this paper retrieves relevant data on AT-aided health and well-being from the ScienceDirect full-text database. As shown in Figure 1, the adopted research methodological flow chart shows five quantitative and qualitative data analysis steps: (1) bibliometric search in ScienceDirect full-text database with "art therapy" as the keyword; (2) source analysis of AT publications: using histograms and pie charts for data analysis; (3) keyword co-occurrence analysis of AT-aided health and well-being: using the visual map of keyword co-occurrence analysis in VOSviewer for data analysis; (4) synthesis of the content and characteristics of each theme category of AT-aided studies; and (5) analysis of research hotspots and future development trends of AT-aided studies.

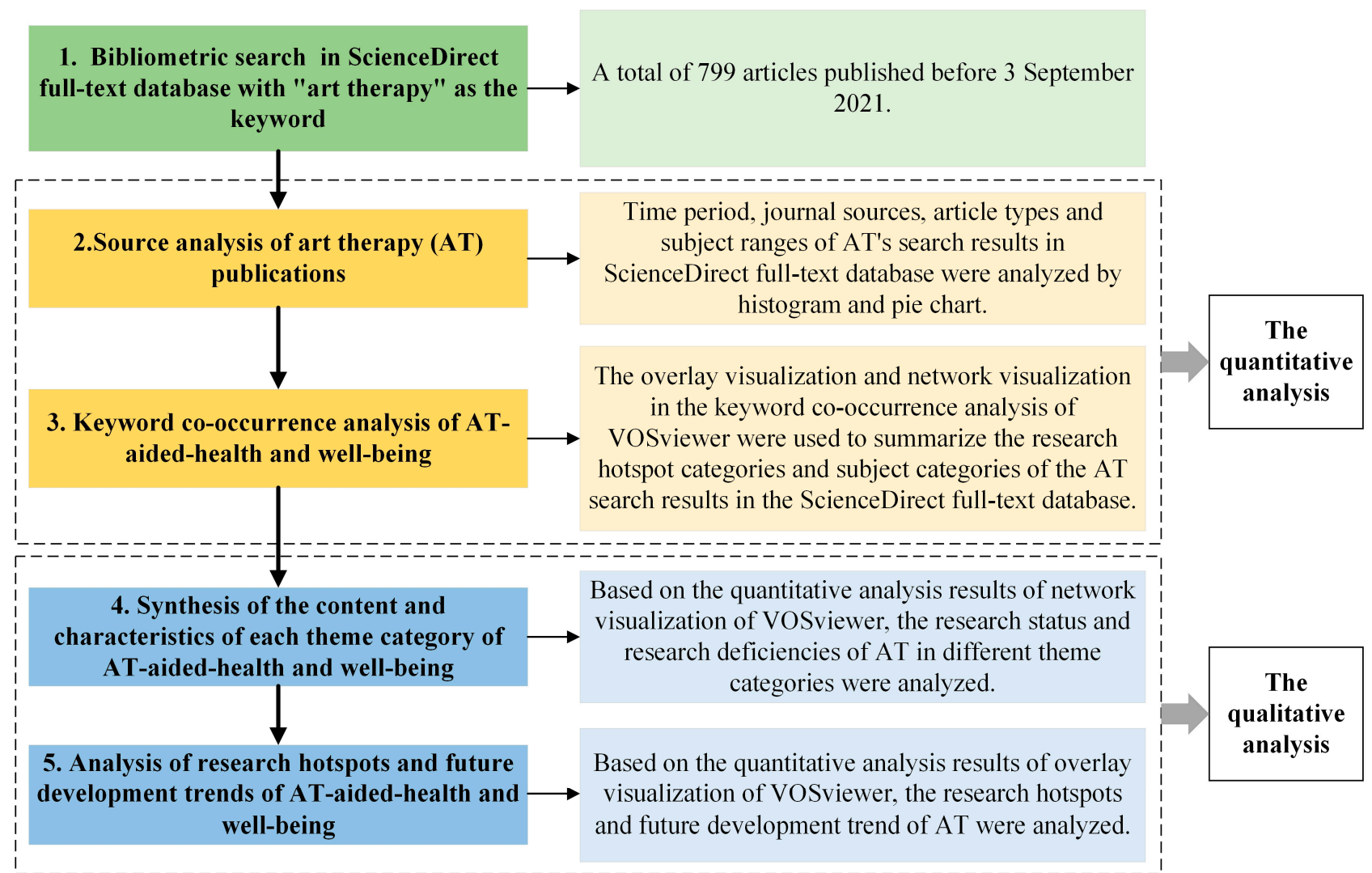

Figure 1. The flow chart of the research methodology. 


\section{Results of the Quantitative Analysis of Art Therapy (AT)-Aided Health and Well-Being}

\subsection{Time Period Analysis}

In ScienceDirect full-text database, the research on the AT-aided health and well-being, which began in year 1946, encompasses a total of 799 published articles in three quarters of a century, spanning 75 years from 1946 to September 2021. These include including 191 articles from 1946 to 1999 and 608 articles from 2000 to 2021, which are shown in chronological order in Figure 2. In general, the number of the articles published on ATaided health and well-being in ScienceDirect has shown an upward trend year-on-year. Since year 2006, the number of the articles ranges between 19 and 51 per year. In the recent two years (2020-2021), the number of the articles per year has reached the maximum so far, exceeding 50 articles, and is still increasing. This indicates that AT is gaining a continuous interest and widespread recognition among researchers.

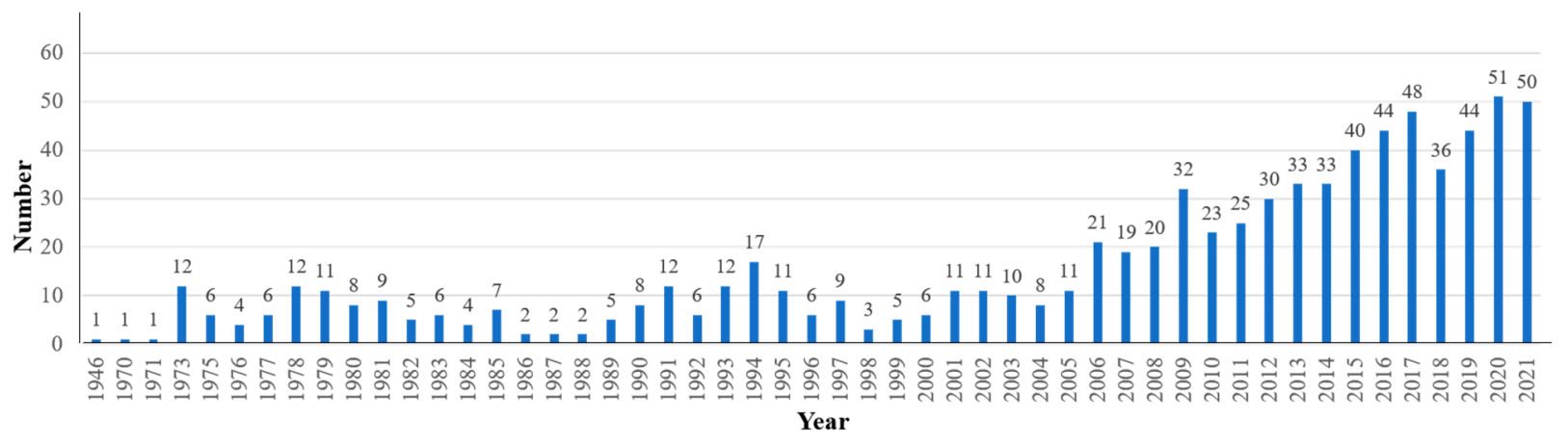

Figure 2. Distribution of articles published on art therapy (AT)-aided health and well-being in three quarters of a century, 75 years from year 1946 to September 2021 in ScienceDirect (devised by the authors).

\subsection{Journal Source Analysis}

In ScienceDirect full-text database, the 799 articles on AT-aided health and well-being are published in 139 academic journals. As shown in Figure 3, the top five journals that publish most articles in the field of AT-aided health and well-being are 'The Arts in Psychotherapy' (formerly known as 'Art Psychotherapy'), 'European Psychiatry', 'Annales Médico-psychologiques, revue psychiatrique', 'Procedia-Social and Behavioral Sciences', and 'Blood'. That said, the AT-aided health and well-being articles were mainly published in the 'The Arts in Psychotherapy' contributing 459 articles, more than half of the total (57.45\%), followed by 'European Psychiatry' journal (5.01\%) with a total of 40 articles.

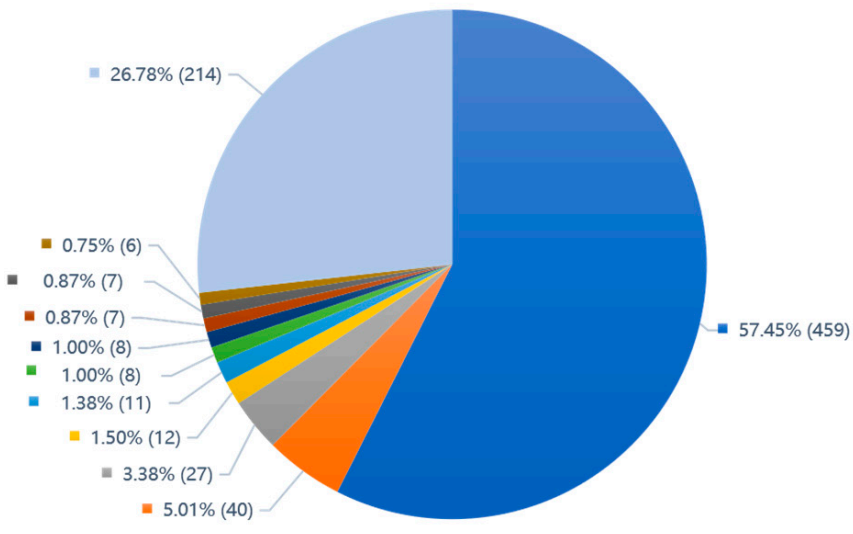

Figure 3. The journals for AT articles published in ScienceDirect (devised by the authors).

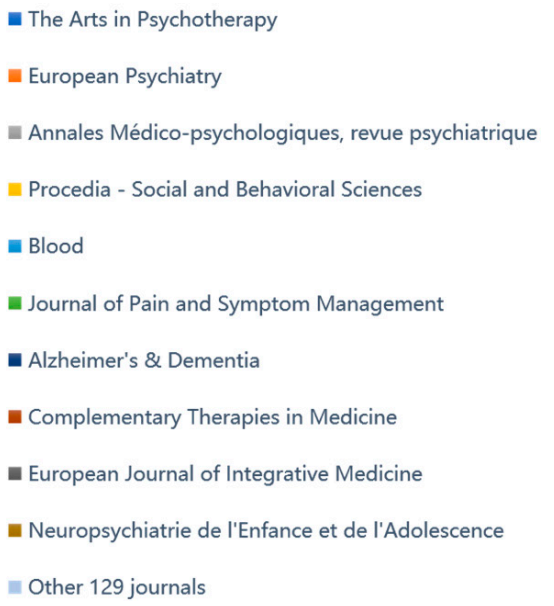




\subsection{Article Type Analysis}

As shown in Figure 4, the types of AT-aided health and well-being articles are principally research articles that have more than 500 articles, followed by conference abstract with 102 abstracts. In addition, there are 57 book reviews, 36 short communications, 29 review articles, and 10 discussions.

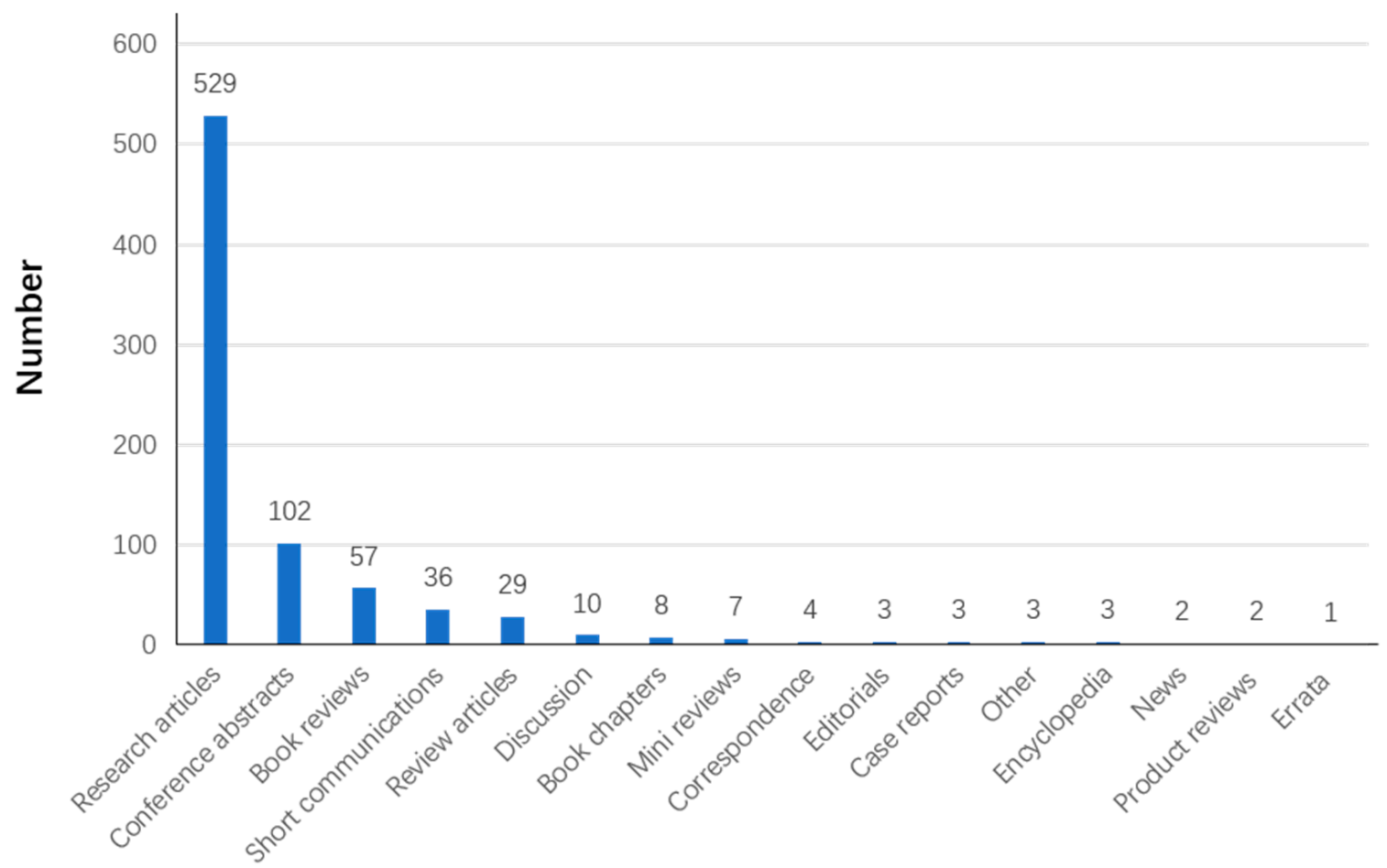

\section{Article type}

Figure 4. The number of different AT article types in ScienceDirect (devised by the authors).

\subsection{Keyword Analysis}

3.4.1. Overlay Visualization of AT-Aided Health and Well-Being

The overlay visualization diagram generated by VOSviewer is shown in Figure 5, which illustrates the color of each keyword changes with the year, and the keywords in the red-orange-yellow circle are the research topics of the recent period. As indicated in Figure 2, the number of articles on AT has reached more than 35 and keeps rising since year 2015. Therefore, the period from recent years 2015 to 2021 is adopted for visual analysis of research hotspots on AT to illustrate current status and future directions. By and large, summarizing the red-orange-yellow keywords in Figure 5, and excluding keywords that are not related to the research topic, such as 'burnout' and 'art therapy protocol', the research hot keywords of AT-aided health and well-being in recent seven years (2015-2021) include five categories: (1) types of AT, e.g., group therapy and group AT; (2) therapeutic methods of AT, e.g., palliative care, mindfulness, dance, body image, memory consolidation, psychodrama, response art, therapeutic meditation, and emotion regulation; (3) research diseases of AT, e.g., schizophrenia; (4) research populations of AT, e.g., veterans, military, child, older adults, and adult; and (5) others: well-being, mental health, and death. It can be illustrated from the connecting relationship between the keywords of the research hotspot in Figure 5 that well-being and mental health are related to each other, where dementia to older adults is associated with mental health, and veterans and military are the main research groups for well-being subjects. 


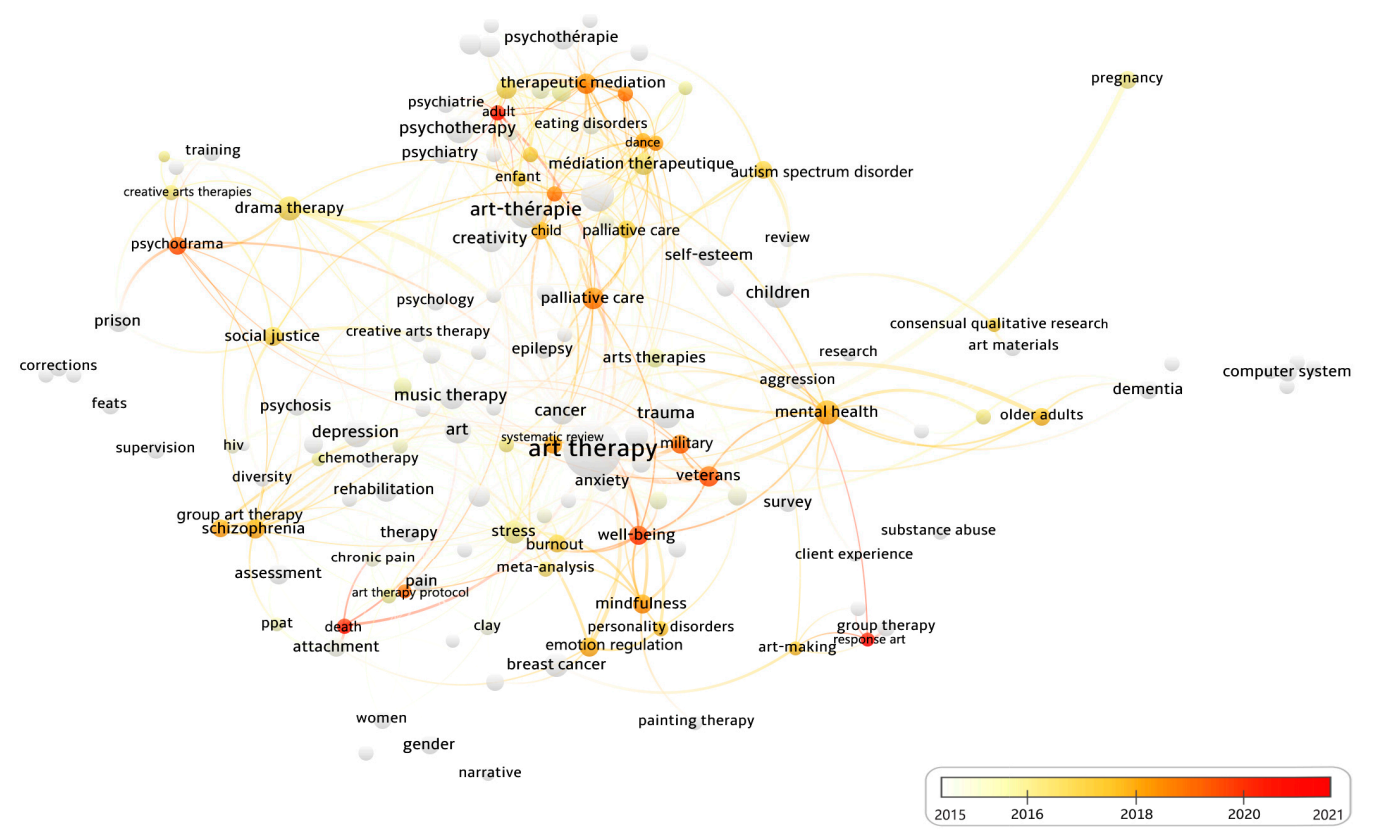

Figure 5. AT-aided health and well-being hotspots from 2015 to 2021 in the Overlay Visualization diagram generated by VOSviewer (devised by the authors).

As shown in Figure 6, well-being appears to be the most dominant AT topic in the latest research in 2021, indicating that AT involves more studies in well-being hotspots. In addition, the recent AT-aided well-being research topics are associated with mental health, COVID-19, palliative care, older adults, drama therapy, stress, psychotherapy, and Parkinson's disease.

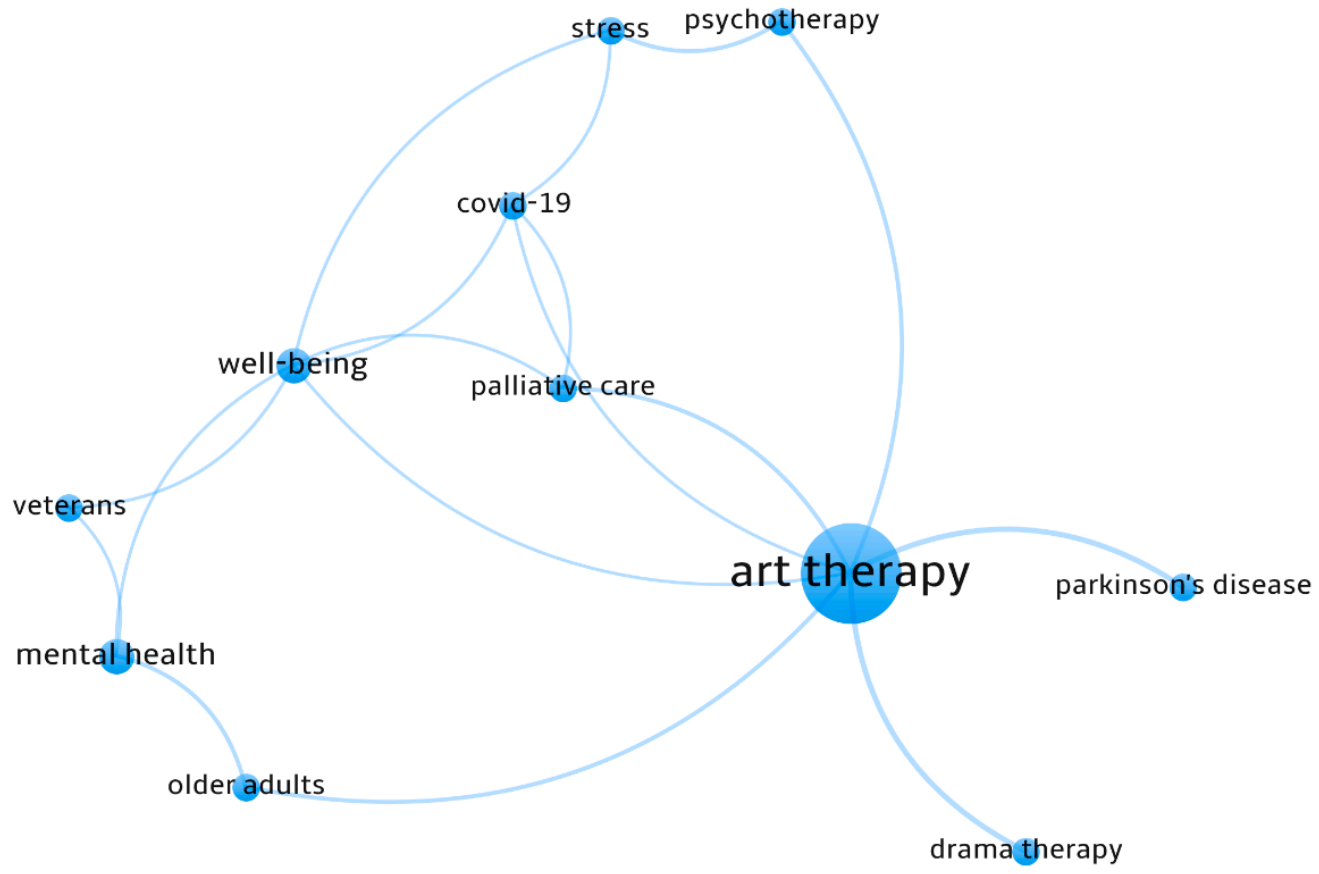

Figure 6. Latest research keywords of AT-aided health and well-being in 2021 via VOSviewer (devised by the authors). 


\subsubsection{Network Visualization of AT-Aided Health and Well-Being}

In the Network Visualization diagram generated by VOSviewer, the more frequently keywords appear in the article, the larger the circle in the diagram and the more closely they are associated with the central theme. Since the VOSviewer software does not automatically merge the repeated synonymous keywords during the co-occurrence analysis of keywords, such as 'art-therapy', 'art-thérapie', and 'art therapy'; 'drama therapy' and 'psychodrama'; and 'creative' and 'creativité'. Therefore, when classifying topics based on Network Visualization diagram, synonymous keywords are manually homogenized. It can be seen from Figure 7 that when AT is the central theme, there are several themes closely related to it, such as trauma, children, music therapy, depression, art, computer system, PTSD, drama therapy, assessment, creative arts therapy (CAT), dance/movement therapy (D/MT), prison, and breast cancer. In the keyword co-occurrence analysis of VOSviewer, circular nodes of different colors indicate different clusters. As shown in Figure 7, associated with the color change, all the keywords of the AT articles are divided into 12 clusters: psychotherapy; depression; cancer; music therapy; breast cancer; veterans; mental health; computer system; palliative care; trauma; children; and pain.

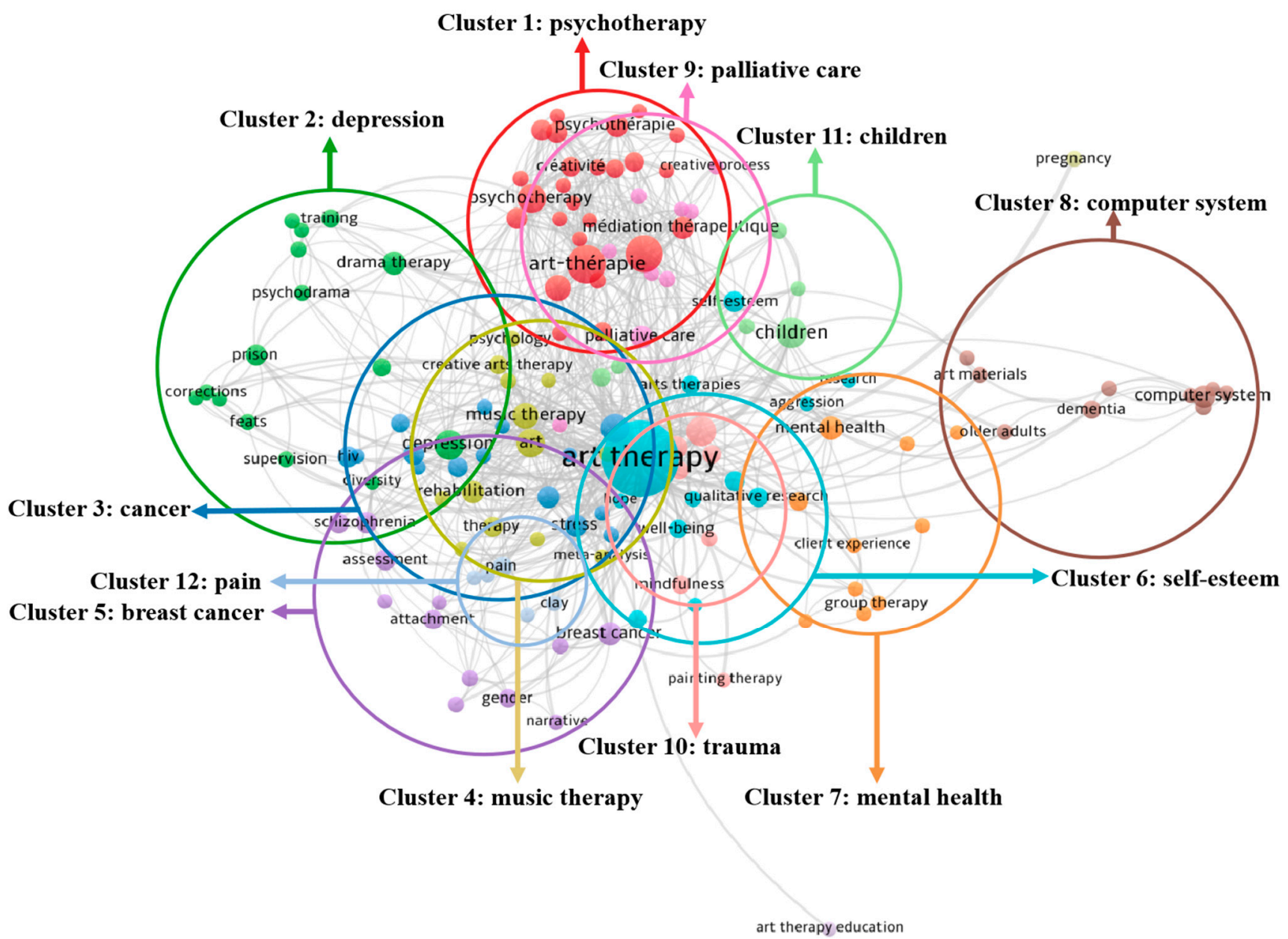

Figure 7. Twelve clusters of AT themes in the Network Visualization diagram generated by VOSviewer (devised by the authors).

In terms of the distance from each cluster to the center of AT in Figure 7, the cancer theme of the cluster 3 and the trauma theme of the cluster 10 are the closest themes to AT, indicating that the studies of AT have the closest relationships with trauma and cancer. On the contrary, the computer system of the cluster 8 is the furthest away from AT, which means that the subject of computer systems to aid AT needs more studies to bring them 
closer. In addition, in terms of the relative positions of the clusters in Figure 7, cluster 1 and cluster 9, cluster 3 and cluster 4 , and cluster 6 and cluster 10 have an obvious intersection relationship, which reveals that psychotherapy and palliative care, cancer and music therapy, and trauma and veterans are closely related to each other. In terms of correlation within a cluster, the positions of CAT, D/MT, and music therapy are more concentrated in the cluster 4, indicating that the themes of this area are closely related.

Based on the keyword co-occurrence analysis results of VOSviewer, keywords that are most closely related to the AT theme are selected for further qualitative analysis in following Section 4. The co-occurrence frequency and total link strength of high-frequency keywords of AT-aided health and well-being are shown in Table 1.

Table 1. High-frequency keywords of art therapy (AT)-aided health and well-being study from year 1946 to September 2021 via network visualization of VOSviewer (devised by the authors).

\begin{tabular}{|c|c|c|c|c|}
\hline Words Color & Cluster & Keyword & Occurrences & $\begin{array}{c}\text { Total Link } \\
\text { Strength }\end{array}$ \\
\hline & 11 & children & 20 & 18.00 \\
\hline & 2 & depression & 17 & 17.00 \\
\hline & 10 & trauma & 17 & 16.00 \\
\hline & 1 & psychotherapy & 16 & 16.00 \\
\hline & 4 & art & 16 & 14.00 \\
\hline & 3 & cancer & 16 & 13.00 \\
\hline & 4 & music therapy & 13 & 13.00 \\
\hline & 1 & creativity & 13 & 13.00 \\
\hline & 2 & drama therapy & 10 & 10.00 \\
\hline & 7 & mental health & 10 & 10.00 \\
\hline & 5 & breast cancer & 10 & 10.00 \\
\hline & 10 & post-traumatic stress disorder (PTSD) & 9 & 9.00 \\
\hline & 3 & stress & 9 & 9.00 \\
\hline & 3 & quality of life & 8 & 8.00 \\
\hline & 9 & palliative care & 8 & 7.00 \\
\hline & 8 & computer system & 8 & 5.00 \\
\hline & 6 & self-esteem & 7 & 7.00 \\
\hline & 2 & prison & 7 & 7.00 \\
\hline & 1 & psychiatry & 7 & 6.00 \\
\hline & 5 & assessment & 7 & 6.00 \\
\hline & 5 & schizophrenia & 7 & 5.00 \\
\hline & 6 & veterans & 6 & 6.00 \\
\hline & 12 & pain & 6 & 6.00 \\
\hline & 12 & anxiety & 6 & 6.00 \\
\hline & 6 & qualitative research & 6 & 5.00 \\
\hline & 5 & group art therapy (AT) & 6 & 4.00 \\
\hline & 5 & well-being & 5 & 5.00 \\
\hline & 1 & Alzheimer's disease & 5 & 5.00 \\
\hline & 11 & epilepsy & 5 & 5.00 \\
\hline & 4 & psychosis & 5 & 5.00 \\
\hline & 8 & dementia & 5 & 5.00 \\
\hline & 10 & military & 5 & 5.00 \\
\hline & 4 & creative arts therapy (CAT) & 5 & 4.00 \\
\hline & 1 & drawing & 5 & 4.00 \\
\hline & 4 & dance/movement therapy (D/MT) & 4 & 4.00 \\
\hline & 11 & adolescents & 4 & 4.00 \\
\hline
\end{tabular}

Table 1 indicates that children (Occurrences: 20, Total link strength: 18), depression (Occurrences: 17, Total link strength: 17), and trauma (Occurrences: 17, Total link strength: 16) have a stronger co-occurrence relationship with AT-aided health and well-being. The AT articles employed primarily qualitative research methods, and the facilitated main diseases that the studies focus on are depression, trauma, and cancer. The treatment methods of AT are mainly related to psychotherapy, music, and drama. The population of AT-aided studies 
concern children, veterans, and adolescents. The reported benefits of AT are associated with improving the quality of life, mental health, self-esteem, and well-being. Moreover, CAT and group AT are the therapeutic categories of AT. Furthermore, the computer system is an important evaluation tool in the research of AT, which helps to further understand the value of AT in promoting health and well-being. Based on the content of Table 1, the existing research of AT-aided health and well-being are further classified by keywords in each cluster into six thematic categories, as shown in Table 2.

Table 2. Six thematic categories of AT-aided health and well-being (devised by the authors).

\begin{tabular}{ccc}
\hline Thematic Category & Table 1 Associated Cluster & Keyword \\
\hline Research methods of AT-aided study & 6 & qualitative research \\
\hline Types of AT & 4,5 & CAT, group AT \\
\hline Research populations of AT & $6,10,11$ & children, veterans, adolescent \\
\hline AT-aided diseases & $1,2,3,4,5,8,10,11,12$ & $\begin{array}{c}\text { depression, trauma, cancer, breast cancer, PTSD, stress, } \\
\text { schizophrenia, pain, anxiety, Alzheimer's disease, epilepsy, } \\
\text { psychosis, dementia }\end{array}$ \\
\hline Therapeutic methods of AT & $1,2,4,9$ & $\begin{array}{r}\text { psychotherapy, music therapy, drama therapy, palliative } \\
\text { care, psychiatry, D/MT, drawing } \\
\text { computer system, assessment }\end{array}$ \\
\hline Evaluation of AT-aided study & 5,8 & comples
\end{tabular}

\section{Results of the Qualitative Analysis of AT-Aided Health and Well-Being}

Based on the results of the above quantitative analysis, this paper qualitatively summarizes the research status of AT-aided health and well-being in ScienceDirect full-text database from the following six thematic categories that are in line with Table 2: (1) research methods of AT-aided health and well-being; (2) types of AT; (3) research populations of AT; (4) AT-aided diseases; (5) therapeutic methods of AT; and (6) evaluation of therapeutic effect of AT-aided health and well-being.

\subsection{Research Methods of AT-Aided Health and Well-Being}

Qualitative research is the main research method of AT [66-68]. In qualitative research, the commonly used methods largely include semi-structured interviews [69-71], focus groups [66,72,73], phenomenological analysis [74-76], thematic analysis [67,77,78], and grounded theory [79-81]. Qualitative research can help with understanding the value of AT in terms of knowledge system, perception, experience, inner change, and perception. Smeijsters and Cleven [66] argue that qualitative investigation methods, such as semistructured questionnaires, interviews, and focus groups, can describe the knowledge system of forensic psychiatric AT based on practice, theory, and research. Moreover, the qualitative research method of phenomenology can be used to understand the views of art therapists and patients on art creation and AT $[69,82,83]$, and the theoretical framework of AT can also be understood from the experience of art therapists [76]. Through the qualitative research method of thematic analysis, the inner changes in patients during AT can be observed, and the inner changes in patients can be described through a common language [77]. In addition, thematic analysis of the results of interviews with professional therapists reveal that the new virtual reality (VR) medium has great potential in AT [84]. Furthermore, qualitative ground theory and interviews can assess the perceived effects of emotional management in patients with personality disorders to understand the effects of AT in clinical practice [80].

\subsection{Types of $A T$}

The types of AT-aided health and well-being mostly include CAT and group AT. CAT is a term used in therapeutic arts disciplines [64], which can use different forms of artistic expression such as music, drama, and dance/movement for treatment. Group AT, in 
which patients participate in the art centered treatment process, mainly includes five art therapeutic factors: symbolic expression; relational aesthetics; embodiment; pleasure/play; and ritual [85]. In group AT, mothers and children are the main research population.

\subsubsection{Creative Arts Therapy (CAT)}

CAT has a certain potential in relieving psychological, behavioral, physiological, and other related diseases. It has been widely used to study military groups. Table 3 summarizes CAT studies in research methods, research populations, research diseases, and therapeutic methods. In CAT research, dance/movement, drama, and music therapy are often integrated [35,86,87]. Moreover, healing CAT from refugee backgrounds has shown a positive impact on young patient's mood and behavior [86]. Research indicated that therapeutic value of CAT in treating traumatized children [51], and CAT have a positive impact on the psychology of patients with breast cancer and gynecological cancer [64]. CAT can also provide rehabilitation services for active military and veterans [88]. Further, telemedicine based on CAT provide healthcare opportunities for veterans [87,89]. In general, CAT help young people recognize and discover the meaning in their feelings; and help them improve their social and psychological functions [43].

Table 3. The list of creative arts therapy (CAT) studies for health and well-being (devised by the authors).

\begin{tabular}{|c|c|c|c|c|c|}
\hline Source & Year & Research Method & $\begin{array}{l}\text { Research } \\
\text { Population }\end{array}$ & Research Disease & Therapeutic Method \\
\hline Aldridge et al. [90] & 1990 & Case study & Art therapist & Epileptic & Painting and music \\
\hline Milliken [91] & 2002 & Case study & Prisoners & Violence & Dance/movement \\
\hline Talwar [92] & 2007 & Case study & Art therapist & PTSD & $\begin{array}{l}\text { Dance, movement, music, } \\
\text { poetry, and tempera }\end{array}$ \\
\hline Brown [93] & 2008 & Experiment & Art therapist & None & $\begin{array}{l}\text { Improvisations, music, } \\
\text { sound, movement, writing, } \\
\text { and art }\end{array}$ \\
\hline Nordstrom-Loeb [94] & 2012 & $\begin{array}{l}\text { Case study and } \\
\text { questionnaire }\end{array}$ & General public & None & Dance/movement \\
\hline $\begin{array}{l}\text { van Westrhenen and } \\
\text { Fritz [51] }\end{array}$ & 2014 & Literature review & Children & Trauma & None \\
\hline Quinlan et al. [86] & 2016 & $\begin{array}{l}\text { Experiment and } \\
\text { questionnaire }\end{array}$ & Adolescents & $\begin{array}{l}\text { Psychological and } \\
\text { behavioral problems }\end{array}$ & $\begin{array}{l}\text { Visual arts and play } \\
\text { activities }\end{array}$ \\
\hline Edwards [95] & 2016 & Literature review & General public & None & $\begin{array}{c}\text { Music, art, and } \\
\text { dance/movement }\end{array}$ \\
\hline $\begin{array}{c}\text { Papagiannaki and } \\
\text { Shinebourne [96] }\end{array}$ & 2016 & Interview & Art therapist & Mental illness & None \\
\hline $\begin{array}{l}\text { Hertrampf and } \\
\text { Wärja [64] }\end{array}$ & 2017 & Literature review & Adult women & $\begin{array}{l}\text { Breast or gynecological } \\
\text { cancer }\end{array}$ & $\begin{array}{l}\text { Music, drama, } \\
\text { dance/movement, and } \\
\text { poetry }\end{array}$ \\
\hline Levy et al. [89] & 2018 & Case study & Veterans & $\begin{array}{l}\text { Mental health care and } \\
\text { rehabilitation }\end{array}$ & $\begin{array}{l}\text { Arts, dance/movement, and } \\
\text { telehealth }\end{array}$ \\
\hline $\begin{array}{c}\text { Hanvey and } \\
\text { Tepper-Lewis [33] }\end{array}$ & 2019 & Case study & $\begin{array}{l}\text { Child and } \\
\text { adolescent }\end{array}$ & Emergency psychiatry & $\begin{array}{l}\text { Dance/movement and } \\
\text { visual art }\end{array}$ \\
\hline Spooner et al. [87] & 2019 & Case study & Veterans & $\begin{array}{l}\text { Mental health care and } \\
\text { rehabilitation }\end{array}$ & $\begin{array}{l}\text { Visual art, } \\
\text { dance/movement, music, } \\
\text { and drawing }\end{array}$ \\
\hline Hylton et al. [35] & 2019 & $\begin{array}{l}\text { Experiment, } \\
\text { questionnaire, } \\
\text { interview }\end{array}$ & Adolescent & $\begin{array}{l}\text { PTSD, depression, and } \\
\text { anxiety }\end{array}$ & Visual art, drama, and music \\
\hline Ali and Haen [88] & 2019 & Literature review & Veterans & Trauma & $\begin{array}{c}\text { Dramatic, movement } \\
\text { performance, music, and } \\
\text { visual arts }\end{array}$ \\
\hline Bechtel et al. [97] & 2020 & Case study & General public & None & Drama and tape sculpture \\
\hline
\end{tabular}




\subsubsection{Group AT}

Group AT has numerous benefits for mothers and children, such as relieving symptoms of depression, fear, anxiety and mood disorders, and improving patients' subjective wellbeing and quality of life. Table 4 lists group AT studies in research methods, research populations, research diseases, and therapeutic methods. Choi and Goo [98] prove that group AT can effectively change the mother's parenting behavior through a mixed research method including experiments, questionnaires, and case studies. For mothers, group AT is able to improve the mental health and well-being of mothers regarding their disabled children [99]. Similarly, for children, group AT improve the overall health-related quality of life of children with cancer [40]; and bring positive effects for children with attention deficit hyperactivity disorder (ADHD) and emotional dysregulation [100]. Moreover, group AT can not only reduce the depression level of elderly patients with neurocognitive disorders patients and improve their ability to express themselves [101], but also reduce the fear of childbirth in late pregnancy [102]. Furthermore, group AT facilitated with respiratory therapy allow anxious patients to recognize their negative emotions, which can reduce anxiety symptoms and improve subjective well-being [103].

Table 4. The list of group AT studies for health and well-being (devised by the authors).

\begin{tabular}{|c|c|c|c|c|c|}
\hline Source & Year & Research Method & $\begin{array}{l}\text { Research } \\
\text { Population }\end{array}$ & Research Disease & Therapeutic Method \\
\hline $\begin{array}{c}\text { Stone and } \\
\text { Williams [104] }\end{array}$ & 1982 & $\begin{array}{l}\text { Experiment and } \\
\text { case study }\end{array}$ & $\begin{array}{l}\text { Mothers of autistic } \\
\text { children }\end{array}$ & Autistic & $\begin{array}{l}\text { Drawing and discussion of } \\
\text { the art work }\end{array}$ \\
\hline Virshup [105] & 1985 & Case study & Drug abusers & $\begin{array}{l}\text { Psychological } \\
\text { problems }\end{array}$ & Drawing \\
\hline Hagood [106] & 1991 & Case study & $\begin{array}{c}\text { Mothers of } \\
\text { sexually abused } \\
\text { children }\end{array}$ & $\begin{array}{l}\text { Psychological } \\
\text { problems }\end{array}$ & $\begin{array}{l}\text { Collage, drawing, and } \\
\text { visual imagery }\end{array}$ \\
\hline Rosal [107] & 1993 & Experiment & Children & Behavior disorder & $\begin{array}{l}\text { Cognitive-behavioral } \\
\text { approach }\end{array}$ \\
\hline Liao and Liu [100] & 2012 & Experiment & Children & $\begin{array}{c}\text { ADHD and } \\
\text { emotional } \\
\text { dysregulation }\end{array}$ & Drawing \\
\hline Choi and Goo [98] & 2012 & $\begin{array}{c}\text { Experiment, } \\
\text { questionnaire, and } \\
\text { case study }\end{array}$ & Mothers & $\begin{array}{l}\text { Mother-child } \\
\text { attachment }\end{array}$ & $\begin{array}{l}\text { Drawing, collage, clay, and } \\
\text { mask }\end{array}$ \\
\hline Jang and Choi [108] & 2012 & $\begin{array}{l}\text { Experiment and } \\
\text { case study }\end{array}$ & Adolescents & Ego-resilience & Clay and pottery work \\
\hline Kim et al. [103] & 2014 & Experiment & Adolescents & $\begin{array}{l}\text { Depression and } \\
\text { anxiety }\end{array}$ & $\begin{array}{l}\text { Breath meditation and } \\
\text { drawing }\end{array}$ \\
\hline Stevenson et al. [109] & 2014 & Experiment & General public & $\begin{array}{l}\text { Non-psychotic } \\
\text { mental health } \\
\text { disorders }\end{array}$ & $\begin{array}{l}\text { Wait-list, art, and verbal } \\
\text { therapy }\end{array}$ \\
\hline Kim et al. [101] & 2016 & Experiment & Older patients & $\begin{array}{l}\text { Neurocognitive } \\
\text { disorders }\end{array}$ & Drawing and art materials \\
\hline $\begin{array}{l}\text { Korostiy and } \\
\text { Hmain [110] }\end{array}$ & 2016 & Experiment & Patients & $\begin{array}{l}\text { Recurrent depressive } \\
\text { disorder }\end{array}$ & $\begin{array}{l}\text { Drawing, clinical, } \\
\text { psychopathological, } \\
\text { psychodiagnostics, and } \\
\text { statistical methods }\end{array}$ \\
\hline Gabel and Robb [85] & 2017 & $\begin{array}{c}\text { Thematic } \\
\text { meta-synthesis }\end{array}$ & General public & None & None \\
\hline $\begin{array}{l}\text { Ünsalver and } \\
\text { Sezen [111] }\end{array}$ & 2017 & $\begin{array}{l}\text { Experiment and } \\
\text { questionnaire }\end{array}$ & Pregnant women & Fear of giving birth & Psychoeducation, group AT \\
\hline
\end{tabular}


Table 4. Cont.

\begin{tabular}{|c|c|c|c|c|c|}
\hline Source & Year & Research Method & $\begin{array}{c}\text { Research } \\
\text { Population }\end{array}$ & Research Disease & Therapeutic Method \\
\hline Kozhyna et al. [30] & 2017 & Experiment & Patients & $\begin{array}{c}\text { Major depressive } \\
\text { disorder }\end{array}$ & Drawing \\
\hline $\begin{array}{l}\text { Abdulah and } \\
\text { Abdulla [40] }\end{array}$ & 2018 & Experiment & Children & Cancer & Painting and handcrafting \\
\hline $\begin{array}{c}\text { Sezen and } \\
\text { Ünsalver [102] }\end{array}$ & 2019 & $\begin{array}{l}\text { Experiment and } \\
\text { questionnaire }\end{array}$ & Pregnant women & Fear of childbirth & $\begin{array}{l}\text { Listening to music and } \\
\text { singing, drawing, } \\
\text { mask-making, } \\
\text { mandala-making, } \\
\text { puppet-making, taking } \\
\text { photographs, and collage } \\
\text { making }\end{array}$ \\
\hline MacDonald et al. [43] & 2019 & $\begin{array}{l}\text { Experiment, case } \\
\text { study, and } \\
\text { questionnaire }\end{array}$ & $\begin{array}{l}\text { Youth and young } \\
\text { adults }\end{array}$ & Diabetes & $\begin{array}{l}\text { Drawing, collage and } \\
\text { creating sculpture from } \\
\text { paper, plasticine, } \\
\text { self-hardening clay, fabrics } \\
\text { or found objects }\end{array}$ \\
\hline Teoli [112] & 2021 & $\begin{array}{l}\text { Cooperative } \\
\text { inquiry, } \\
\text { companioning, } \\
\text { and art-based } \\
\text { research } \\
\text { (interview) }\end{array}$ & Art therapists & $\begin{array}{c}\text { Alzheimer's, } \\
\text { dementia, } \\
\text { developmental } \\
\text { disabilities, PTSD, } \\
\text { anxiety, and } \\
\text { psychological } \\
\text { problems }\end{array}$ & Art making \\
\hline Van Lith et al. [113] & 2021 & $\begin{array}{l}\text { Experiment and } \\
\text { questionnaire }\end{array}$ & Children & $\begin{array}{l}\text { Mental health } \\
\text { problems }\end{array}$ & $\begin{array}{l}\text { Collage, drawing, and art } \\
\text { materials (i.e., clay, } \\
\text { materials) }\end{array}$ \\
\hline Lee [99] & 2021 & $\begin{array}{l}\text { Experiment and } \\
\text { questionnaire }\end{array}$ & $\begin{array}{l}\text { Mothers of } \\
\text { children with } \\
\text { disabilities }\end{array}$ & $\begin{array}{l}\text { Parenting stress, } \\
\text { perceived stress, } \\
\text { depression, and } \\
\text { perceived social } \\
\text { support }\end{array}$ & Drawing and collage \\
\hline
\end{tabular}

\subsection{Research Populations of AT}

The research population of AT-aided health and well-being chiefly focusses on children, veterans, and adolescents.

\subsubsection{Children}

AT-aided health and well-being with children as the research population largely adopt a mixed/hybrid research method integrating experiment, interview, questionnaire, and case studies [114-116]. AT tends to have a positive therapeutic effect on children's behaviors, learning disabilities, trauma, autism, and other diseases. Indeed, AT can improve their academic performance [117], enhance emotional and behavioral adaptability [115], and reduce anger and improve self-esteem [24]. The integration of AT and music helps with developing and coordinating children's personal abilities with special needs, which can help them integrate into society [118]. In addition, AT helps with reducing the trauma and stress symptoms of children [119], as well as improve the social/emotional skills of children with autism [120]. AT for improving self-image brings qualitative benefits to children with epilepsy [72] and autism spectrum disorder [116]. Further, drawing and painting is a commonly used form of AT-aided health and well-being for children because art therapists can understand brain activity in the process of drawing, which in turn, provides guidance for the theory and practice of AT [121]. Using drawing as a medium, AT 
improves understanding the personal experience of art therapists in treating aggressive children [122]. Drawing in a less threatening manner can relieve symptoms of ADHD and emotional dysregulation in children [100] and help children with epilepsy to express their feelings in non-verbal ways [123]. Using painting as an expression to explore emotions enable mother and child to solve depressed inner conflicts and reduce the fear of exposing oneself in the AT process [124].

\subsubsection{Veterans}

The research of AT on the veterans group mainly adopts the case study method [12,36,125]. In the military population, PTSD and traumatic brain injury (TBI) are the most frequently interfered by AT. AT can help with understanding the inner experience of veterans with PTSD to promote trauma treatment [36]. Long-term AT is capable of improving the overall quality of life of soldiers [125], as well as satisfaction of PTSD and TBI patients with treatment and experience positive emotions, thereby reducing the symptoms of trauma [18]. AT is gradually being accepted as a form of care for military groups by helping senior soldiers with PTSD and TBI overcome psychological and physical symptoms [12]. With the development of technology, telemedicine based AT provides veterans with opportunities for mental health care and rehabilitation $[87,89]$.

\subsubsection{Adolescents}

The majority of AT-aided health and well-being on adolescents use case analysis research method [23,126,127], which largely discuss the therapeutic effect of AT on the neural, psychological, and behavioral problems of adolescents. In addition, group AT is a more effective form of treatment for adolescents [128]. When group AT is associated with respiratory therapy, it can stimulate the emotional and human characteristics of adolescents and significantly improve the subjective well-being of anxious adolescents [103]. Moreover, clay-based group AT has a positive impact on adolescents' self-resilience [108]. CAT improves neurasthenic adolescents' symptoms through stretching exercises and walking meditation [129]. Further, AT can help with reducing hopelessness, suicidal determination, and symptoms of PTSD for suicidal adolescents [23].

\subsection{AT-Aided Diseases}

AT-aided diseases are largely focused on five aspects: (1) trauma and PTSD; (2) depression; (3) schizophrenia and psychosis; (4) Alzheimer's disease and dementia; and (5) cancer.

\subsubsection{Trauma and Post-Traumatic Stress Disorder (PTSD)}

AT-aided health and well-being for trauma and PTSD mostly conducted via case study research method [12,14,125]. AT provides non-verbal treatment for trauma patients [14]. The scope of traumatic events mostly includes war, post-disaster, and displacement. The most common artistic method for treating trauma and PTSD is drawing, which is presented in different forms such as bridge, self-portrait, and mandala. Trauma is a non-verbal problem concept [130]. Non-verbal value can be discovered through artistic creation [12]. Hence, AT is an effective, non-verbal treatment method in solving trauma-related problems [14]. In the context of war, AT provides soldiers with an opportunity to explore their experiences, thoughts, and feelings through a nonverbal way [131]. The trauma children experience after a disaster can be treated with semi-structured artistic interventions [132]. Moreover, AT helps displaced people with strengthening their connection with society [128]. In the process of AT based on painting, the visual art form of bridge drawing can provide an AT opportunity for orphans who have experienced psychological trauma [133]. Among them, drawing in the form of self-portrait is able to reduce the impact of traumatic events [134]. Furthermore, the drawing form of the mandala is capable of facilitating the emotional catharsis of sex trafficking survivors and solve trauma problems [14]. 


\subsubsection{Depression}

AT-aided health and well-being on depression primarily implement experimental research methods with scales [100,102,133], and clinical diagnostic methods $[28,110,135]$. AT can replace medical treatment to help relieve the symptoms of patients with depression and anxiety [136]. AT in the form of drawing improves depression in cancer patients [39]. In the experimental method, the evaluation with the Beck Depression Inventory (BDI) scale proves that AT is effective in reducing the depressive symptoms of male and female prisoners [137]. Group AT improves the depression condition among the elderly [101], and integrates respiratory therapy to heighten the well-being of anxious adolescents [103]. In addition, in the process of artistic creation, patients with depression recognize themselves through inner dialogue [138], and effectively alleviate various symptoms of patients with major depressive disorder through artistic psychotherapy [139]. Further, studies in clinical diagnosis highlight that AT is an effective psychotherapy method for depression [28], which has the ability to improve the quality of treatment and life of patients with depression [135].

\subsubsection{Schizophrenia and Psychosis}

AT-aided studies principally employ case study research methods [140-142] and experiment $[32,109,143]$ in investigating schizophrenia and psychosis. AT is one of the new techniques of human psychiatry, which can relieve and cure psychological disorders [144]. Using artistic creation as a medium may affect psychopathology and reduce the incidence of schizophrenia by strengthening the patient's self-awareness [145]. When AT is facilitated with psychological education, psychiatric symptoms can be rapidly improved [141]. Paintings created by psychiatric patients provide an opportunity to perceive the patient's inner world [140]. The intervention of AT in female patients with schizophrenia reduces symptoms and improves cognitive function [32]. However, there is no clear conclusion on the evidence of the efficacy and effectiveness of AT for patients with schizophrenia [146,147]. Although AT has uncertain evidence for the effectiveness of psychosis, many art therapists and psychiatric patients believe that AT is a beneficial, meaningful, and acceptable intervention [27].

\subsubsection{Alzheimer's Disease and Dementia}

Case studies were predominantly used in the AT-aided disease research to treat Alzheimer's disease and dementia $[20,148,149]$. AT is part of non-drug treatment for patients with Alzheimer's disease and dementia [20], which can relieve behavioral symptoms, and improve patients' self-esteem, quality of life, and happiness [150]. In the AT-aided Alzheimer's disease, a human-centered approach increases the convenience of the nursing process, in which empathy builds trust between the therapist and the patient [151]. Visiting museums and expressing AT improve the self-esteem and positive behavior of patients with Alzheimer's disease [19]. In the care of dementia patients, participation in the intervention of AT enable dementia patients to alleviate the behavioral and psychological symptoms [37,150], improve the quality of life and well-being of patients [20], and may also help caregivers maintain health and improve well-being [148]. Hence, AT is seen as a valuable resource for solving mental health difficulties and/or challenges caused by dementia [38].

\subsubsection{Cancer}

AT-aided cancer treatment studies have been conducted via a mixed research method using experiment, interview, and questionnaire $[39,152,153]$. Drawing is the most common form of AT to aid cancer patients. It has been reported that drawing activity in AT improves the mental health and quality of life of cancer chemotherapy patients $[39,40,49]$. In addition, the intervention of artistic creation can relieve the symptoms of cancer [154]; and is also beneficial to the stressful caregivers of cancer patients [18]. For cancer patients, AT is often associated with palliative care to reduce pain and symptoms [155], which improves the quality of life of the cancer patients [22]. 
Breast cancer is the disease that has been paid the most attention regarding the use of AT to treat cancer. The 'Coping Resources Inventory' is a commonly used assessment method, in which quality of life, fatigue, and subjective well-being are commonly used assessment elements in the process of AT treating breast cancer patients. It is able to explain and help with understanding the female image of breast cancer patients [156]; and prove that AT has important and positive significance in supporting health and coping resources in the short term [157]. In addition, the integration of cognitive behavioral intervention into AT can help the treatment of breast cancer patients. The artistic creation process of AT improves the quality of life [158], reduces fatigue symptoms [152], and enhances selfefficacy of breast cancer patients [159]. Reynolds and Lim [69] conducted a qualitative study revealing that artistic creation in the process of AT enables women with breast cancer to improve the subjective well-being and establish a positive life experience. Interestingly, artbased cognitive-behavioral therapy (CBT) was found to reduce anxiety and pain symptoms of breast cancer patients [160].

\subsection{Therapeutic Methods of AT}

The therapeutic methods of AT are twofold: psychology, and artistic creation. In addition to the drawing mentioned in Sections 4.3.1 and 4.4.1, the therapeutic methods of AT-aided health and well-being include psychotherapy, drama therapy, music therapy, and D/MT.

\subsubsection{Psychotherapy}

Psychotherapy is a biopsychosocial method in the process of AT [10]. Art psychotherapy brings positive changes to both staff and patients [161], such as promoting life coping skills, improving psycho-neural immune function, and enhancing interpersonal relationships [10]. There are various approaches of art psychotherapy, such as parent-child art psychotherapy, and mindful art psychotherapy. Parent-child art psychotherapy refers to paying attention to changes in the parent-child relationship in the presentation of art materials [162]. The use of parent-child art psychotherapy in the education system improves children's emotional function, interpersonal relationship, and learning ability in a regular school environment [68]. The use of art in mindfulness-based psychotherapy can restore the cognitive reserve of the elderly, and improve mood and the pursuit of meaningful activities after retirement [163]. In addition, mindfulness art psychotherapy based on digital light therapy technology can help the elderly to externalize and express emotions; and improve symptoms of anxiety and depression [164]. The great potential of integrating technologies in art psychotherapy, such as VR, and light therapy, can accelerate and expand the process of AT. Using VR environment as a therapeutic environment in psychotherapy is able to bring possibilities for the innovation of artistic creation and constitute a new medium for AT [84].

\subsubsection{Drama Therapy}

Drama is a friendly art form [165], as an additional embodiment of therapeutic artistic creation [97], associated with music therapy has a better therapeutic effect. Drama therapy facilitated with Interpretive Phenomenological Analysis (IPA) methods can effectively promote the treatment process. In the process of drama therapy, the integration of IPA method to analyze the experience of the creative art therapist is capable of alleviating the patient's sense of self-insult, improve the therapist's chances of understanding the patient, which contributes to the patient's mental health [96]. In addition to understanding the experience of art therapists, IPA can also understand prisoners' views on CAT in prison [82]. Moreover, the comprehensive psychological drama theory, and the model of CBT and narrative therapy (CBN Psychodrama) improve the self-control of high-risk adolescents [166]. The CAT-aided drama and music has the potential to reduce the symptoms of traumatic stress caused by school shootings in teenagers [35]. Furthermore, it was evidenced that 
drama therapy has a positive effect on severe mental patients [143], and has improved the emotional state of forensic patients [167].

\subsubsection{Music Therapy}

Music therapy provides opportunities to treat behavioral, psychological, and cognitive disorders [168]. It is often associated with drama, dance/movement, and cognitionbehavior to study the therapeutic effects of AT on different diseases. Music-based CAT can alleviate the emotional symptoms and behavioral problems of refugee youth [86], and may also be valuable in the treatment of drug abuse disorders [169]. Furthermore, CBT-based music improves anger management skills in forensic psychiatry [170]; and may also be an effective intervention for the treatment of fatigue in blood and bone marrow transplant patients [171]. Further, the integration of art and music therapy enable children with special problems to has a general, nonverbal advantage [119].

\subsubsection{Dance/Movement Therapy (D/MT)}

D/MT is a new field of CAT [91], which largely focuses on mental illnesses, such as PTSD, mental disorders, emotions, and stress. It helps with exploring the psychological and behavioral changes in children suffering from PTSD after an earthquake; and providing cohesion for a group of children with mental disorders [172]. Additionally, D/MT has certain positive effects in reducing negative emotions [173] and alleviating stress problems [174]. It focuses on physiological diseases, such as breast cancer and nasopharyngeal carcinoma. D/MT for cancer patients can reduce their stress and improve their self-esteem [175]. In the disorder of behavior, the use of D/MT can deal with violence in prison [91]. Among the symptoms of perceived relief, D/MT utilizes video interpretation to help patients relieve pain symptoms [176]. Although D/MT has a positive therapeutic effect on many diseases, many articles indicate that a larger, complete, and blind random sample is needed for the specific discussion of D/MT [177-179].

\subsection{Evaluation of Therapeutic Effect of AT-Aided Health and Well-Being}

The computer system acts as an evaluation tool for AT-aided health and well-being. Table 5 summarizes the studies for computer system in the evaluation of therapeutic effect on AT-aided health and well-being. It can also be used as an auxiliary treatment tool for AT [180]. Color is a commonly used and effective evaluation index for the computer systems. By evaluating the colors in AT paintings, the effectiveness of the computer system can be verified [181], and it also provide useful information for the evaluation results of AT [182]. Among the various drawing forms evaluated by the computer system, mandala and Person Picking an Apple from a Tree (PPAT) are common methods. In addition, the stepwise regression model is a commonly used method for studies using computer systems. When using a stepwise regression model, multiple art treatment methods can be compared, among which PPAT is the best treatment method for patients with dementia [183]. In addition, the use of PPAT for evaluation also prove that human-machine evaluation tools may be more accurate than human perception [184]. A computer AT system for kinetic family drawing can bring objective and accurate evaluation for the evaluation of AT [185]. When using a computer system to evaluate the various elements of structured mandala, quantitative data could be generated to facilitate the decision-making process of experts [186]. 
Table 5. The list of studies for computer system in the evaluation of therapeutic effect on AT-aided health and well-being (devised by the authors).

\begin{tabular}{|c|c|c|c|c|c|}
\hline Source & Year & Research Method & $\begin{array}{c}\text { Research } \\
\text { Population }\end{array}$ & $\begin{array}{l}\text { Research } \\
\text { Disease }\end{array}$ & Therapeutic Method \\
\hline $\begin{array}{l}\text { Hartwich and } \\
\text { Brandecker [180] }\end{array}$ & 1997 & Case study & Inpatient & $\begin{array}{c}\text { Borderline case } \\
\text { personality disorder and } \\
\text { psychotic diseases }\end{array}$ & $\begin{array}{l}\text { Drawing and } \\
\text { psychotherapy }\end{array}$ \\
\hline Kim et al. [181] & 2007 & Case study & General public & None & Drawing \\
\hline Kim et al. [182] & 2008 & Case study & General public & None & Drawing \\
\hline Kim et al. [186] & 2009 & $\begin{array}{l}\text { Experiment and case } \\
\text { study }\end{array}$ & Old persons & Dementia & Structured mandalas \\
\hline Mihailidis et al. [73] & 2010 & $\begin{array}{l}\text { Participatory design } \\
\text { (ethnography, } \\
\text { questionnaire, and } \\
\text { interview) }\end{array}$ & General public & Dementia & $\begin{array}{l}\text { Visual arts, music, writing, } \\
\text { painting, sculpture, } \\
\text { and dance }\end{array}$ \\
\hline Mattson [187] & 2010 & Literature review & General public & None & None \\
\hline Kim et al. [185] & 2011 & $\begin{array}{l}\text { Questionnaire and } \\
\text { case study }\end{array}$ & General public & None & Kinetic family drawing \\
\hline Mattson [184] & 2011 & Experiment & $\begin{array}{l}\text { Middle-aged } \\
\text { adults }\end{array}$ & Schizophrenia & $\begin{array}{l}\text { Drawing (person picking } \\
\text { an apple from a tree) }\end{array}$ \\
\hline Kim et al. [183] & 2012 & $\begin{array}{l}\text { Regression model } \\
\text { and case study }\end{array}$ & Elderly people & Dementia & $\begin{array}{l}\text { Painting (person picking } \\
\text { an apple from a tree, face } \\
\text { stimulus assessment, and } \\
\text { structured mandala } \\
\text { coloring) }\end{array}$ \\
\hline Mattson [188] & 2015 & $\begin{array}{c}\text { Usability evaluation } \\
\text { (questionnaire and } \\
\text { interview) }\end{array}$ & General public & None & Drawing \\
\hline Kim et al. [101] & 2016 & Experiment & Older patients & Neurocognitive disorders & Drawing and art materials \\
\hline
\end{tabular}

\section{Discussion}

\subsection{Research Hotspots and Development Trends of AT-Aided Health and Well-Being}

Based on the quantitative and qualitative analysis results of this paper, it can be seen that group AT, children, and schizophrenia are the key themes of AT-aided health and well-being. There was consensus in the reviewed literature that AT is able to improve the quality of life and well-being of patients with Alzheimer's disease, dementia, and breast cancer. Overall, the qualitative analysis results also show that well-being and mental health are closely related to AT.

The research hotspots of AT-aided studies from 2015 to 2021, primarily revolve around therapeutic methods and population. The four therapeutic methods of psychotherapy, drama, music, and D/MT all bring potential value to improve mood and psychological disorders. AT is also often associated with palliative care to explore the therapeutic effect. In addition to alleviating the symptoms of patients, AT-based palliative care interventions help patients and their relatives to improve their sensory, emotional, cognitive, and spiritual experiences [189], elevating the quality of life [22] and the effect of mood therapy [190]. Using dual AT between palliative care patients and their caregivers can protect the dignity of dying patients and their caregivers [191]. Kometiani and Farmer [14] believe that in the palliative care environment, using "representative art", that is, art therapists to create works of art on behalf of patients, can facilitate the treatment of patients affected by fatigue and other serious diseases.

Among the hot research population on AT, in addition to children, adolescents and veterans, the elderly has also become the key research population of AT. The positive 
therapeutic effect of AT on the elderly is mainly reflected in helping them prevent cognitive decline [192], and improving the ability of older survivors to share and process their stories and find meaning in life [193].

Furthermore, the results of AT-aided health and well-being indicate that among the latest research keywords in 2021, the research content of AT also revolves regarding the keyword of COVID-19. In the context of the COVID-19 pandemic, Hass-Cohen et al. [194] studied the effects of pain, depression, anxiety, interpersonal relationships, helplessness, and resources on patients participating in AT using drawing as a medium, before and after the pandemic, and found that the frequency of experiencing hopefulness of participants before the pandemic increased with time, while the frequency of experiencing hopefulness of participants after the pandemic decreased with time. From the perspective of research hotspots, the future development trend of AT may be based on research hotspots, such as group AT, children, schizophrenia, well-being, mental health, palliative care, veterans, and the elderly, for the COVID-19 pandemic associated topic.

\subsection{New Therapeutic Methods for AT-Aided Health and Well-Being}

The results reveal that the primary therapeutic methods of AT-aided health and wellbeing include psychotherapy, D/MT, drama, music, and drawing. Drawing includes self-portrait, mandala, PPAT, and bridge drawing as its approaches. In addition, ATaided cognitive behavior is an effective method to promote health, which focuses on the therapeutic effect of facilitating behavior with psychodrama [166,195], and music [170,171]. CBT is considered a broad psychological approach [196], which helps to increase selfesteem [197] and reduce anxiety symptoms [198]. However, although CBT is a beneficial treatment method, the application of behavior as the CBT research theme with AT is few and new, which needs further investigation. In addition to CBT, D/MT has positive therapeutic value in the treatment of a number of diseases, such as autism, cancer, and PTSD. D/MT is a creative psychotherapy method based on the movement metaphor [199], whereby using the kinesthetic experience of movement metaphor, schizophrenic patients can express their emotions through words [200]. However, the specific effects of D/MT require more consideration, such as improving interpersonal competence [62], alleviating psychotic symptoms in patients with schizophrenia [173], and reducing emotional eating in obese women [201], which presents the status quo of insufficient research on D/MT. From the perspective of research deficiencies, there is a need for the future research of behavior and movement in AT-aided study towards promoting health and well-being, where the new therapeutic methods can be explored to enhance potential value of AT.

\subsection{Emerging Technology Enhanced AT-Aided Health and Well-Being}

In the light of mega digital era, AT needs to utilize continuously evolving emerging technologies to make an effective intervention in its process. The application of emerging technology includes digital technology and remote technology, such as VR, digital phototherapy technology, computer technology, and telemedicine technology in the current state of AT-aided health and well-being. Mihailidis et al. [73] argue that the field of AT requires technical solutions to meet the needs of therapists and patients. Digital technology can be used for the training of art therapists to understand the relevant ethics of using digital media [202]. In the application of digital technology, computer technology is primarily used for the evaluation of the effect of AT, and VR is implemented to aid the process of AT. In addition, the experiment of professional art therapists using VR technology to create visual art shows that the VR medium has a great potential to facilitate process of AT [84]. Although the VR technology has shown a potential therapeutic value in delivering AT, there are insufficient studies on the application of VR technology to aid AT treatment, which is still in its infancy. Compared with digital technology, remote technology is mostly used in the rehabilitation and health care services of veterans [87]. However, remote supervision is mostly conducted in general counseling and education fields, with few applications in the field of AT [203]. Interestingly, among the various technologies, only digital technology and 
remote technology are commonly used in AT. By and large, while emerging technologies have enhanced AT for health and well-being, there are insufficient studies in the field of AT that integrate digital technology and remote technology for therapeutic intervention in neither methods nor approaches.

\section{Conclusions}

With the use of mixed research method, this paper summarizes the current situation, hot spots, deficiencies, and future research trends of the practical application of AT from both quantitative and qualitative aspects in promoting health and well-being, which provides specific content and direction for the potential practical value of AT. This paper has three main contributions: (1) this paper is the first mixed research method to incorporate AT articles of 75 years (3/4 century) by using visual keyword co-occurrence. This comprehensive research result has reference value for AT researchers, educators, and healthcare practitioners and can provide pathways for information and communications technology (ICT) development for information visualization software suppliers. (2) This paper is the first attempt to use bibliometric analysis which includes keyword co-occurrence analysis to classify AT-aided study status in ScienceDirect full-text database from 1946 to September 2021. VOSviewer, a tool for visualizing bibliometric graphs, is used for keyword co-occurrence analysis. It is able to gain insights into AT related topics through visualized keyword maps. With the help of VOSviewer, the systematically mixed quantitative and qualitative analysis summarizes the research categories, research hotspots, and research deficiencies of AT, which provide a reliable research method for the future study of AT. (3) This paper finds that the research status of AT-aided study primarily includes research methods, types, populations, diseases, therapeutic methods, and evaluation of six themes. The hot keywords of AT-aided health and well-being mainly focus on group AT, children, schizophrenia, well-being, mental health, palliative care, veterans, and the elderly, which may be used as a basis to analyze the background of the COVID-19 in the future AT-aided health and well-being. In addition, in spite of the gaps and shortcomings in the exploration of AT in behavior, movement, and technology, the integration and innovation of behavior, movement, and technology in the field of AT is a multidimensional breakthrough in promoting health and well-being. However, the research in this paper has certain limitations. Different researchers may use different keywords to express the same meaning due to differences in terms used by individuals, such as 'older adults' representing 'the elderly', which could affect the retrieval effect. In addition, VOSviewer software cannot automatically homogenize repeated synonymous keywords when performing keyword co-occurrence analysis. As such, manual homogenization of keywords may lead to slight deviations in data analysis. Further, this paper only conducts bibliometric analysis on a single ScienceDirect database, and does not extend the search data of AT to multiple databases in different fields such as health, society, and art. Future research could be based on the research status and research limitations of AT to systematically conduct visual analysis from multiple databases, such as Web of Science and Scopus, in order to create more application values for various social situations, such as COVID-19. Further, based on the research in the fields of behavior, movement, and technology, the therapeutic effect of AT could be analyzed more comprehensively and concretely from the aspect of promoting health and well-being.

Author Contributions: Conceptualization, Z.L., Z.Y., C.X. and K.Z.; methodology, Z.L., Z.Y., C.X., K.Z. and M.O.; software, Z.Y.; formal analysis, Z.Y.; investigation, Z.L., Z.Y. and C.X.; resources, Z.L., C.X. and K.Z.; data curation, Z.L. and Z.Y.; writing-original draft preparation, Z.L. and Z.Y.; writing-review and editing, Z.L., Z.Y., C.X., K.Z. and M.O.; validation, Z.L. and Z.Y.; visualization, Z.Y.; supervision, Z.L.; project administration, Z.L., C.X. and K.Z.; funding acquisition, Z.L., C.X. and K.Z. All authors have read and agreed to the published version of the manuscript. 
Funding: This research was funded by Guangdong Province Education Science Planning Project, "Research on Youth Psychological/Mind Models and Art Therapy Strategies: Taking Greater Bay Area University as an Example": grant number 2019GXJK196.

Institutional Review Board Statement: Not applicable.

Informed Consent Statement: Not applicable.

Data Availability Statement: Publicly available datasets were analyzed in this study. These data can be found here: https:/ / www.sciencedirect.com/ (accessed on 30 September 2021).

Acknowledgments: The authors would like to thank all the people who support this research including anonymous reviewers for their putting forward constructive suggestions to this paper. Z.L. would like to thank a-year-and-eight-month Isabella who inspired him to do this meaningful art therapy study during his expecting, waiting, and doing for her in the COVID-19 epidemic since 2019. Z.Y. would like to thank her family, friends, and supervisor for their encouragements and trusts in her believing her mind of perseverance until success, especially, her teammates for their helping, her supervisor for his patient guidance word by word during a whole year of writing, and the School of Design, South China University of Technology, for providing rich data resources and learning environment.

Conflicts of Interest: The authors declare that there is no conflict of interest.

\section{References}

1. Sohrabi, C.; Alsafi, Z.; O’Neill, N.; Khan, M.; Kerwan, A.; Al-Jabir, A.; Iosifidis, C.; Agha, R. World Health Organization declares global emergency: A review of the 2019 novel coronavirus (COVID-19). Int. J. Surg. 2020, 76, 71-76. [CrossRef]

2. Lippi, G.; Henry, B.M.; Bovo, C.; Sanchis-Gomar, F. Health risks and potential remedies during prolonged lockdowns for coronavirus disease 2019 (COVID-19). Diagnosis 2020, 7, 85-90. [CrossRef]

3. Haghani, M.; Bliemer, M.C.; Goerlandt, F.; Li, J. The scientific literature on Coronaviruses, COVID-19 and its associated safetyrelated research dimensions: A scientometric analysis and scoping review. Saf. Sci. 2020, 129, 104806. [CrossRef]

4. Mancl, D.; Fraser, S.D. COVID-19's Influence on the Future of Agile. In Agile Processes in Software Engineering and Extreme Programming-Workshops. XP 2020, Proceedings of the Lecture Notes in Business Information Processing, Copenhagen, Denmark, 8-12 June 2020; Paasivaara, M., Kruchten, P., Eds.; Springer: Cham, Switzerland, 2020; Volume 396, pp. 309-316.

5. Coronavirus Disease 2019 (COVID-19) I CDC. Available online: https://www.cdc.gov/coronavirus/2019-nCoV/index.html (accessed on 14 December 2021).

6. Matias, T.; Dominski, F.H.; Marks, D.F. Human needs in COVID-19 isolation. J. Health Psychol. 2020, 25, 871-882. [CrossRef]

7. Brooks, S.K.; Webster, R.K.; Smith, L.E.; Woodland, L.; Wessely, S.; Greenberg, N.; Rubin, G.J. The psychological impact of quarantine and how to reduce it: Rapid review of the evidence. Lancet 2020, 395, 912-920. [CrossRef]

8. Imran, N.; Zeshan, M.; Pervaiz, Z. Mental health considerations for children \& adolescents in COVID-19 Pandemic. Pak. J. Med. Sci. 2020, 36, S67-S72.

9. Naeim, M.; Rezaeisharif, A.; Kamran, A. COVID-19 Has Made the Elderly Lonelier. Dement. Geriatr. Cogn. Disord. Extra 2021, 11, 26-28. [CrossRef]

10. Virago, M.C. Art psychotherapy and public health. Public Health 2021, 196, 150-157. [CrossRef]

11. Gruber, H.; Weis, J. Therapeutic action in art therapy: Results of an empirical study. Eur. J. Integr. Med. 2010, 4, 179. [CrossRef]

12. Walker, M.S.; Kaimal, G.; Koffman, R.; DeGraba, T.J. Art therapy for PTSD and TBI A senior active duty military service member's therapeutic journey. Arts Psychother. 2016, 49, 10-18. [CrossRef]

13. Moss, H.; Brady, C.; Kelly, B. A fuller picture: Evaluating an art therapy programme in a multi-disciplinary mental health service. Eur. Psychiatry 2017, 41, S612. [CrossRef]

14. Kometiani, M.K.; Farmer, K.W. Exploring resilience through case studies of art therapy with sex trafficking survivors and their advocates. Arts Psychother. 2020, 67, 101582. [CrossRef]

15. Toroghi, L.M. The effectiveness of art therapy on housewives general health, anxiety and self-efficacy in tehran. Eur. Psychiatry 2015, 30, 852. [CrossRef]

16. Raluca, B.O.; Bocoş, M. Formative influence of preschoolers through art education. Procedia-Soc. Behav. Sci. 2013, 76, 71-76. [CrossRef]

17. Stojkovic, J.P.; Milosavljevic, M.; Vukovic, M.; Vidic, L.; Tosevski, D.L. The importance of art therapy in the integrative treatment of recurrent depressive disorder-case study. Eur. Psychiatry 2016, 33, S418. [CrossRef]

18. Kaimal, G.; Jones, J.P.; Dieterich-Hartwell, R.; Acharya, B.; Wang, X. Evaluation of long-and short-term art therapy interventions in an integrative care setting for military service members with post-traumatic stress and traumatic brain injury. Arts Psychother. 2019, 62, 28-36. [CrossRef]

19. Duncan, A.C.; Huebner, B. P2-521: A Journey of Self Proclamation through Museum Tours and Expressive ART Therapy: Bridging the GAP Between Society and Alzheimer's Disease. Alzheimer's Dement. 2018, 14, P935. [CrossRef] 
20. Boudebza, A.; Jeannot, D.; Lamy, S.; Roudier, M.; Al Aloucy, M.J. Art et cognition: Atelier d'expression artistique dans un hôpital de jour spécialisé Alzheimer. NPG Neurol.-Psychiatr.-Gériatrie 2006, 6, 18-20. [CrossRef]

21. Ostroski, R.; Bruscato, A.M.; Moro, A.; Tommasi, S. P4-161: The interdisciplinary speech therapy and art therapy and enhancing quality of life: A case study. Alzheimer's Dement. 2011, 7, S760. [CrossRef]

22. Thanasilp, S.; Voraakhom, K.; Pisolayabutra, P.; Panriansaen, R.; Tantitrakul, W.; Akkaayagorn, L. The Effect of a Dharma Creative Art Therapy Program Among Cancer Patients Receiving Palliative Care. J. Pain Symptom Manag. 2018, 56, e22-e23. [CrossRef]

23. Harnden, B.; Rosales, A.B.; Greenfield, B. Outpatient art therapy with a suicidal adolescent female. Arts Psychother. 2004, 31, 165-180. [CrossRef]

24. Mousavi, M.; Sohrabi, N. Effects of art therapy on anger and self-esteem in aggressive children. Procedia-Soc. Behav. Sci. 2014, $113,111-117$.

25. Pesso-Aviv, T.; Regev, D.; Guttmann, J. The unique therapeutic effect of different art materials on psychological aspects of 7-to 9-year-old children. Arts Psychother. 2014, 41, 293-301. [CrossRef]

26. Hanes, M.J. House as a mirror of self: A case study of a twenty-one-year-old female in an inpatient psychiatric hospital. Arts Psychother. 2019, 66, 101601. [CrossRef]

27. Attard, A.; Larkin, M. Art therapy for people with psychosis: A narrative review of the literature. Lancet Psychiatry 2016, 3, 1067-1078. [CrossRef]

28. Korostiy, V.; Hmain, S. Art-therapy in Complex Treatment of Major Depressive Disorder. Eur. Psychiatry 2015, 30, 1324. [CrossRef]

29. Laroque, F.; Sudres, J.L. Le patient dépressif en art-thérapie: Évaluation des bénéfices et recommandations pratiques. Ann. Médico-Psychol. Rev. Psychiatr. 2015, 173, 541-546. [CrossRef]

30. Kozhyna, H.; Korostiy, V.; Hmain, S.; Mykhaylov, V. The use of art therapy in complex treatment on the quality of remission in patients with melancholy in major depressive disorder. Eur. Psychiatry 2017, 41, s777. [CrossRef]

31. Hanevik, H.; Hestad, K.A.; Lien, L.; Teglbjaerg, H.S.; Danbolt, L.J. Expressive art therapy for psychosis: A multiple case study. Arts Psychother. 2013, 40, 312-321. [CrossRef]

32. Rizk, D.N.; Darwish, S.; Cover, I.; Radwan, A.H.; Esmail, M. Effect of Group Art Intervention on Clinical Symptoms and Cognitive Functions in Female Patients with Schizophrenia. Eur. Psychiatry 2015, 30, 1. [CrossRef]

33. Hanvey, C.; Tepper-Lewis, C. Co-leading for community building: A program description of a dual-modality creative arts therapy group in psychiatric emergency care. Arts Psychother. 2019, 66, 101581. [CrossRef]

34. Kalmanowitz, D.; Ho, R.T.H. Out of our mind. Art therapy and mindfulness with refugees, politicalviolence and trauma. Arts Psychother. 2016, 49, 57-65. [CrossRef]

35. Hylton, E.; Malley, A.; Ironson, G. Improvements in adolescent mental health and positive affect using creative arts therapy after a school shooting: A pilot study. Arts Psychother. 2019, 65, 101586. [CrossRef]

36. Lobban, J.; Murphy, D. Understanding the role art therapy can take in treating veterans with chronic post-traumatic stress disorder. Arts Psychother. 2019, 62, 37-44. [CrossRef]

37. Mak, B.; Woo, J.; Kou, W.; Tse, R. Art therapy for demented elderly: A pilot study. Alzheimer's Dement. 2009 , 4, e25.

38. Elliott, M.; Jones, J.; Elliott, M.; Challenger, S.; Guise, V.; Jones, E.; Waite, L. Expanding arts therapies provision: A pilot project in Older Adult Mental Health Services, Aneurin Bevan University Health Board. Public Health 2021, 194, 270-273. [CrossRef] [PubMed]

39. Bozcuk, H.; Ozcan, K.; Erdogan, C.; Mutlu, H.; Demir, M.; Coskun, S. A comparative study of art therapy in cancer patients receiving chemotherapy and improvement in quality of life by watercolor painting. Complement. Ther. Med. 2017, 30, 67-72 [CrossRef] [PubMed]

40. Abdulah, D.M.; Abdulla, B.M.O. Effectiveness of group art therapy on quality of life in paediatric patients with cancer: A randomized controlled trial. Complement. Ther. Med. 2018, 41, 180-185. [CrossRef]

41. Kaimal, G.; Carroll-Haskins, K.; Mensinger, J.L.; Dieterich-Hartwell, R.M.; Manders, E.; Levin, W.P. Outcomes of art therapy and coloring for professional and informal caregivers of patients in a radiation oncology unit: A mixed methods pilot study. Eur. J. Oncol. Nurs. 2019, 42, 153-161. [CrossRef] [PubMed]

42. Macdonald, C.; Marks, S. Creative Arts Diabetes Initiative: Art Therapy for Young Adults with Type 2 Diabetes Transitioning from Pediatric to Adult Care. Can. J. Diabetes 2018, 42, S41. [CrossRef]

43. MacDonald, C.; Friedman, S.; Marks, S.D. Creative arts diabetes initiative: Group art therapy and peer support for youth and young adults transitioning from pediatric to adult diabetes care in Manitoba, Canada. Can. J. Diabetes 2019, 43, 377-383. [CrossRef]

44. Slaght, J.L.; Copenace, S.; Macdonald, C.; Dart, A.; Wicklow, B.A. 7-Evaluation of a Novel Approach to Health-Care Delivery: The Inclusion of an Indigenous Knowledge Keeper and Art Therapy in a Youth Onset Type 2 Diabetes Clinic. Can. J. Diabetes 2020, 44, S3-S4. [CrossRef]

45. Wright, T.; Liang, Y. Examining the Scholarly Literature: A Bibliometric Study of Journal Articles Related to Sustainability and the Arts. Sustainability 2019, 11, 3780. [CrossRef]

46. Shrivastava, P.; Ivanaj, V.; Ivanaj, S. Sustainable development and the arts. Int. J. Technol. Manag. 2012, 60, 23-43. [CrossRef]

47. Braus, M.; Morton, B. Art therapy in the time of COVID-19. Psychol. Trauma 2020, 12, S267. [CrossRef] [PubMed]

48. Shon, C.B.; Lee, J.Y. Phenomenological Case Study of the Experience of Telehealth Digital Art Therapy in a Self-quarantined Person before Confirmed with COVID-19. J. Korea Contents Assoc. 2020, 20, 646-658. 
49. Geue, K.; Goetze, H.; Buttstaedt, M.; Kleinert, E.; Richter, D.; Singer, S. An overview of art therapy interventions for cancer patients and the results of research. Complement. Ther. Med. 2010, 18, 160-170. [CrossRef]

50. Eaton, L.G.; Doherty, K.L.; Widrick, R.M. A review of research and methods used to establish art therapy as an effective treatment method for traumatized children. Arts Psychother. 2007, 34, 256-262. [CrossRef]

51. Van Westrhenen, N.; Fritz, E. Creative Arts Therapy as treatment for child trauma: An overview. Arts Psychother. 2014, 41, 527-534. [CrossRef]

52. Masika, G.M.; Yu, D.S.; Li, P.W. P1-075: Visual ART Therapy as an Option to Tackle Cognitive Decline and the Associated Psychological Symptoms among Older Adults: A Systematic Review and META-Analysis. Alzheimer's Dement. 2019, 15, P263-P264. [CrossRef]

53. Zhong, L.; Zhang, L.; Li, Y.; Liang, X.; Kong, L.; Shen, X.; Wu, T. Assessment of the Toxicity of Quantum Dots through Biliometric Analysis. Int. J. Environ. Res. Public Health 2021, 18, 5768. [CrossRef]

54. Faust, O. Documenting and predicting topic changes in Computers in Biology and Medicine: A bibliometric keyword analysis from 1990 to 2017. Inform. Med. Unlocked 2018, 11, 15-27. [CrossRef]

55. Liu, R.; Lin, H.; Zhao, H. Research on Field Characteristics of Shared Earth System Science Data Using Keyword Analysis and Visualization. Procedia Environ. Sci. 2011, 10, 561-567. [CrossRef]

56. Feng, L.; Leng, F. Development of Theoretical Studies of Co-Word Analysis. J. Libr. Sci. China 2006, 32, 88-92.

57. Fu, H.Z.; Wang, M.H.; Ho, Y.S. Mapping of drinking water research: A bibliometric analysis of research output during $1992-2011$. Sci. Total Environ. 2013, 443, 757-765. [CrossRef]

58. Van Eck, N.J.; Waltman, L. Software survey: VOSviewer, a computer program for bibliometric mapping. Scientometrics 2010, 84, 523-538. [CrossRef] [PubMed]

59. Vaartio-Rajalin, H.; Santamäki-Fischer, R.; Jokisalo, P.; Fagerström, L. Art making and expressive art therapy in adult health and nursing care: A scoping review. Int. J. Nurs. Sci. 2020, 8, 102-119. [CrossRef]

60. Aguilar, B.A. The Efficacy of Art Therapy in Pediatric Oncology Patients: An Integrative Literature Review. J. Pediatr. Nurs. 2017, 36, 173-178. [CrossRef] [PubMed]

61. Crane, T.; Buultjens, M.; Fenner, P. Art-based interventions during pregnancy to support women's wellbeing: An integrative review. Women Birth 2021, 34, 325-334. [CrossRef]

62. Koch, S.; Kunz, T.; Lykou, S.; Cruz, R. Effects of dance movement therapy and dance on health-related psychological outcomes: A meta-analysis. Arts Psychother. 2014, 41, 46-64. [CrossRef]

63. Newland, P.; Bettencourt, B.A. Effectiveness of Mindfulness-Based Art Therapy for Symptoms of Anxiety, Depression, and Fatigue: A Systematic Review and Meta-Analysis. Complement. Ther. Clin. Pract. 2020, 41, 101246. [CrossRef]

64. Hertrampf, R.S.; Wärja, M. The effect of creative arts therapy and arts medicine on psychological outcomes in women with breast or gynecological cancer: A systematic review of arts-based interventions. Arts Psychother. 2017, 56, 93-110. [CrossRef]

65. About ScienceDirect I Premier Platform for Discovering Peer-Reviewed Scientific, Technical and Medical Information I Elsevier. Available online: https:/ / www.elsevier.com/solutions/sciencedirect (accessed on 23 October 2021).

66. Smeijsters, H.; Cleven, G. The treatment of aggression using arts therapies in forensic psychiatry: Results of a qualitative inquiry. Arts Psychother. 2006, 33, 37-58. [CrossRef]

67. Rankanen, M. Clients' positive and negative experiences of experiential art therapy group process. Arts Psychother. 2014, 41, 193-204. [CrossRef]

68. Tamir, R.; Regev, D. Characteristics of parent-child art psychotherapy in the education system. Arts Psychother. 2021, 72, 101725. [CrossRef]

69. Reynolds, F.; Lim, K.H. Contribution of visual art-making to the subjective well-being of women living with cancer: A qualitative study. Arts Psychother. 2007, 34, 1-10. [CrossRef]

70. Regev, D.; Green-Orlovich, A.; Snir, S. Art therapy in schools-The therapist's perspective. Arts Psychother. 2015, 45, 47-55. [CrossRef]

71. Regev, D.; Chasday, H.; Snir, S. Silence during art therapy-The client's perspective. Arts Psychother. 2016, 48, 69-75. [CrossRef]

72. Stafstrom, C.E.; Havlena, J.; Krezinski, A.J. Art therapy focus groups for children and adolescents with epilepsy. Epilepsy Behav. 2012, 24, 227-233. [CrossRef]

73. Mihailidis, A.; Blunsden, S.; Boger, J.; Richards, B.; Zutis, K.; Young, L.; Hoey, J. Towards the development of a technology for art therapy and dementia: Definition of needs and design constraints. Arts Psychother. 2010, 37, 293-300. [CrossRef]

74. Huss, E. Toward a social critical, analytical prism in art therapy: The example of marginalized Bedouin women's images. Arts Psychother. 2016, 50, 84-90. [CrossRef]

75. Gross-Cohen, I.; Eisikovits, Z. My body was telling me the direction:" The bodily dimension in the dance/movement therapists working experiences. Arts Psychother. 2018, 61, 57-65. [CrossRef]

76. Gerlitz, Y.; Regev, D.; Snir, S. A Relational approach to art therapy. Arts Psychother. 2020, 68, 101644. [CrossRef]

77. Holmqvist, G.; Roxberg, A.; Larsson, I.; Lundqvist-Persson, C. What art therapists consider to be patient's inner change and how it may appear during art therapy. Arts Psychother. 2017, 56, 45-52. [CrossRef]

78. Shakarov, I.; Regev, D.; Snir, S.; Orkibi, H.; Adoni-Kroyanker, M. Helpful and hindering events in art therapy as perceived by art therapists in the educational system. Arts Psychother. 2019, 63, 31-39. [CrossRef] 
79. Pénzes, A.; Hooren, S.V.; Dokter, D.; Smeijsters, H. Material interaction in art therapy assessment. Arts Psychother. 2014, 41, 484-492. [CrossRef]

80. Haeyen, S.; Van Hooren, S.; Hutschemaekers, G. Perceived effects of art therapy in the treatment of personality disorders, cluster B/C: A qualitative study. Arts Psychother. 2015, 45, 1-10. [CrossRef]

81. Salomon, M.; Levinger, S. The experience of art therapists who work in private practice when retaining clients' artworks after therapy termination. Arts Psychother. 2020, 70, 101684. [CrossRef]

82. Barak, A.; Stebbins, A. Imaginary dialogues: Witnessing in prison-based creative arts therapies. Arts Psychother. 2017, 56, 53-60. [CrossRef]

83. Goldner, L.; Ruderman, Y. Toward creating positive masculinity? Art therapy as seen by male art therapists and male adolescent clients. Arts Psychother. 2020, 68, 101613. [CrossRef]

84. Hacmun, I.; Regev, D.; Salomon, R. Artistic creation in virtual reality for art therapy: A qualitative study with expert art therapists Arts Psychother. 2021, 72, 101745. [CrossRef]

85. Gabel, A.; Robb, M. (Re)considering psychological constructs: A thematic synthesis defining five therapeutic factors in group art therapy. Arts Psychother. 2017, 55, 126-135. [CrossRef]

86. Quinlan, R.; Schweitzer, R.D.; Khawaja, N.; Griffin, J. Evaluation of a school-based creative arts therapy programme foradolescents from refugee backgrounds. Arts Psychother. 2016, 47, 72-78. [CrossRef]

87. Spooner, H.; Lee, J.B.; Langston, D.G.; Sonke, J.; Myers, K.J.; Levy, C.E. Using distance technology to deliver the creative arts therapies to veterans: Case studies in art, dance/movement and music therapy. Arts Psychother. 2019, 62, 12-18. [CrossRef]

88. Ali, A.; Haen, C. Creative arts therapies and the military: Integrating research and practice in the service of active duty members and veterans. Arts Psychother. 2019, 62, 2-4. [CrossRef]

89. Levy, C.E.; Spooner, H.; Lee, J.B.; Sonke, J.; Myers, K.; Snow, E. Telehealth-based creative arts therapy: Transforming mental health and rehabilitation care for rural veterans. Arts Psychother. 2018, 57, 20-26. [CrossRef]

90. Aldridge, D.; Brandt, G.; Wohler, D. Toward a common language among the creative art therapies. Arts Psychother. 1990, 17, 189-195. [CrossRef]

91. Milliken, R. Dance/movement therapy as a creative arts therapy approach in prison to the treatment of violence. Arts Psychother. 2002, 29, 203-206. [CrossRef]

92. Talwar, S. Accessing traumatic memory through art making: An art therapy trauma protocol (ATTP). Arts Psychother. 2007, 34, 22-35. [CrossRef]

93. Brown, C. The importance of making art for the creative arts therapist: An artistic inquiry. Arts Psychother. 2008, 35, 201-208. [CrossRef]

94. Nordstrom-Loeb, B.E. The emergence of dance/movement therapy in Estonia. Arts Psychother. 2012, 39, 321-327. [CrossRef]

95. Edwards, J. The breadth and depth of contemporary creative arts therapy publications and research. Arts Psychother. 2016, 51, A1. [CrossRef]

96. Papagiannaki, A.; Shinebourne, P. The contribution of creative art therapies to promoting mental health: Using Interpretative Phenomenological Analysis to study therapists' understandings of working with self-stigmatisation. Arts Psychother. 2016, 50, 66-74. [CrossRef]

97. Bechtel, A.; Wood, L.L.; Teoli, L. Re-shaping body image: Tape sculptures as arts-based social justice. Arts Psychother. 2020, 68, 101615. [CrossRef]

98. Choi, S.; Goo, K. Holding environment: The effects of group art therapy on mother-child attachment. Arts Psychother. 2012, 39, 19-24. [CrossRef]

99. Lee, J.H. Effectiveness of group art therapy for mothers of children with disabilities. Arts Psychother. 2021, 73, 101754. [CrossRef]

100. Liao, Y.; Liu, S. Effectiveness of group art therapy for children with ADHD and emotional dysregulation. Neuropsychiatr. L'enfance L'adolesc. 2012, 5, S301-S302. [CrossRef]

101. Kim, H.-K.; Kim, K.M.; Nomura, S. The effect of group art therapy on older Korean adults with Neurocognitive Disorders. Arts Psychother. 2016, 47, 48-54. [CrossRef]

102. Sezen, C.; Ünsalver, B.Ö. Group art therapy for the management of fear of childbirth. Arts Psychother. 2019, 64, 9-19. [CrossRef]

103. Kim, S.; Kim, G.; Ki, J. Effects of group art therapy combined with breath meditation on the subjective well-being of depressed and anxious adolescents. Arts Psychother. 2014, 41, 519-526. [CrossRef]

104. Stone, B.S.; Williams, S. Group art therapy with mothers of autistic children. Arts Psychother. 1982, 9, 31-48. [CrossRef]

105. Virshup, E. Group Art Therapy in a Methadone Clinic Lobby. J. Subst. Abus. Treat. 1985, 2, 153-158. [CrossRef]

106. Hagood, M.M. Group art therapy with mothers of sexually abused children. Arts Psychother. 1991, 18, 17-27. [CrossRef]

107. Rosal, M.L. Comparative group art therapy research to evaluate changes in locus of control in behavior disordered children. Arts Psychother. 1993, 20, 231-241. [CrossRef]

108. Jang, H.; Choi, S. Increasing ego-resilience using clay with low SES (Social Economic Status) adolescents in group art therapy. Arts Psychother. 2012, 39, 245-250. [CrossRef]

109. Stevenson, M.; Rawdin, A.; Uttley, L.; Sutton, A. The Cost Effectiveness of Group Art Therapy for Patients with Non-Psychotic Mental Health Disorders in England and Wales. Value Health 2014, 17, A458-A459. [CrossRef] [PubMed]

110. Korostiy, V.; Hmain, S. Influence of art therapy in complex treatment on the quality of remission in patients with recurrent depressive disorder. Eur. Psychiatry 2016, 33, S559. [CrossRef] 
111. Ünsalver, B.Ö.; Sezen, C. Group art therapy for the management of fear of giving birth. Eur. Psychiatry 2017, 41, s909. [CrossRef]

112. Teoli, L.A. Companioning artmaking: Creating art alongside clients in group art therapy. Arts Psychother. 2021, 75, 101806. [CrossRef]

113. Van Lith, T.; Quintero, A.; Johns, S.; Grzywacz, J.G. Promoting kindergarten readiness using early intervention art therapy with Latinx farmworker children. Arts Psychother. 2021, 73, 101753. [CrossRef]

114. Nissimov-Nahum, E. A model for art therapy in educational settings with children who behave aggressively. Arts Psychother. 2008, 35, 341-348. [CrossRef]

115. Lee, S.L.; Liu, H.L.A. A pilot study of art therapy for children with special educational needs in Hong Kong. Arts Psychother. 2016, 51, 24-29. [CrossRef]

116. Schweizer, C.; Knorth, E.J.; Van Yperen, T.A.; Spreen, M. Evaluation of 'Images of Self', an art therapy program for children diagnosed with autism spectrum disorders (ASD). Child. Youth Serv. Rev. 2020, 116, 105207. [CrossRef]

117. Freilich, R.; Shechtman, Z. The contribution of art therapy to the social, emotional, and academic adjustment of children with learning disabilities. Arts Psychother. 2010, 37, 97-105. [CrossRef]

118. Petruta-Maria, C. The role of art and music therapy techniques in the educational system of children with special problems. Procedia-Soc. Behav. Sci. 2015, 187, 277-282. [CrossRef]

119. Feen-Calligan, H.; Grasser, L.R.; Debryn, J.; Nasser, S.; Jackson, C.; Seguin, D.; Javanbakht, A. Art therapy with Syrian refugee youth in the United States: An intervention study. Arts Psychother. 2020, 69, 101665. [CrossRef]

120. Thayer, F.; Bloomfield, B.S. An evaluation of a developmental individual differences relationship-based (DIR ${ }^{\circledR}$ )-creative arts therapies program for children with autism. Arts Psychother. 2021, 73, 101752. [CrossRef]

121. Griffith, F.J.; Bingman, V.P. Drawing on the brain: An ALE meta-analysis of functional brain activation during drawing. Arts Psychother. 2020, 71, 101690. [CrossRef]

122. Nissimov-Nahum, E. Use of a drawing task to study art therapists' personal experiences in treating aggressive children. Arts Psychother. 2009, 36, 140-147. [CrossRef]

123. Stafstrom, C.E. Using artwork to understand and address the psychosocial challenges facing children and adolescents with epilepsy. Epilepsy Behav. 2019, 101, 106572. [CrossRef]

124. Shin, S.K.; Choi, S.N.; Park, S.W. A narrative inquiry into a mother-child art therapy experience: A self-exploration of the therapist and the mother. Arts Psychother. 2016, 47, 23-30. [CrossRef]

125. Jones, J.P.; Drass, J.M.; Kaimal, G. Art therapy for military service members with post-traumatic stress and traumatic brain injury: Three case reports highlighting trajectories of treatment and recovery. Arts Psychother. 2019, 63, 18-30. [CrossRef]

126. Elkis-Abuhoff, D.L. Art therapy applied to an adolescent with Asperger's syndrome. Arts Psychother. 2008, 35, 262-270. [CrossRef]

127. Czamanski-Cohen, J. "Oh! Now I remember": The use of a studio approach to art therapy with internally displaced people. Arts Psychother. 2010, 37, 407-413. [CrossRef]

128. Gatta, M.; Gallo, C.; Vianello, M. Art therapy groups for adolescents with personality disorders. Arts Psychother. 2014, 41, 1-6. [CrossRef]

129. Kim, S.; Ki, J. A case study on the effects of the with stretching and walking meditation-Focusing on the improvement of emotional expression and alleviation of somatisation symptoms in a neurasthenic adolescent. Arts Psychother. 2014, 41, 71-78. [CrossRef]

130. Gantt, L.; Tinnin, L.W. Support for a neurobiological view of trauma with implications for art therapy. Arts Psychother. 2009, 36, 148-153. [CrossRef]

131. Lande, R.G.; Tarpley, V.; Francis, J.L.; Boucher, R. Combat trauma art therapy scale. Arts Psychother. 2010, 37, 42-45. [CrossRef]

132. Orr, P.P. Art therapy with children after a disaster: A content analysis. Arts Psychother. 2007, 34, 350-361. [CrossRef]

133. Darewych, O. Building bridges with institutionalized orphans in Ukraine: An art therapy pilot study. Arts Psychother. 2013, 40, 85-93. [CrossRef]

134. Hass-Cohen, N.; Bokoch, R.; Findlay, J.C.; Witting, A.B. A four-drawing art therapy trauma and resiliency protocol study. Arts Psychother. 2018, 61, 44-56. [CrossRef]

135. Korostiy, V.; Hmain, S. 2335-Art therapy in the treatment of patients with depressive disorder. Eur. Psychiatry $2013,28,1$. [CrossRef]

136. Mitchell, C.R.; Mitchell, E.S. PMH3 Effects of ART Therapy on Depression and Anxiety in Patients Undergoing Medical Treatment: A Systematic Review. Value Health 2020, 23, S584. [CrossRef]

137. Gussak, D. Comparing the effectiveness of art therapy on depression and locus of control of male and female inmates. Arts Psychother. 2009, 36, 202-207. [CrossRef]

138. Blomdahl, C.; Wijk, H.; Guregård, S.; Rusner, M. Meeting oneself in inner dialogue: A manual-based Phenomenological Art Therapy as experienced by patients diagnosed with moderate to severe depression. Arts Psychother. 2018, 59, 17-24. [CrossRef]

139. Choi, H.; Jung, D.J.; Jeon, Y.H.; Kim, M.J. The effects of combining art psychotherapy with pharmacotherapy in treating major depressive disorder: Randomized control study. Arts Psychother. 2020, 70, 101689. [CrossRef]

140. Derganc, M.; Savs, A.P.; Care, K. 1720-From psychosis to remission through artistic expression. Eur. Psychiatry 2013, $28,1$. [CrossRef] 
141. Kozhyna, H.; Korostiy, V.; Crystal, A. An Integrated System of the Rehabilitation of Patients with Schizophrenia. Eur. Psychiatry 2015, 30, 1. [CrossRef]

142. Shore, A.; Rush, S. Finding clarity in chaos: Art therapy lessons from a psychiatric Hospital. Arts Psychother. 2019, 66, 101575 [CrossRef]

143. Sancar, F.; Şahin, S.; Şahin, G.; Eren, N. The assessment of a drama therapy process for patients with severe psychiatric patients. Eur. Psychiatry 2017, 41, S615. [CrossRef]

144. Farokhi, M. Art therapy in humanistic psychiatry. Procedia-Soc. Behav. Sci. 2011, 30, 2088-2092. [CrossRef]

145. Teglbjaerg, H.S. P0375-Art therapy may reduce schizophrenic psychopathology by strengthening the patient's sense of self. Eur. Psychiatry 2008, 23, S409. [CrossRef]

146. Bastiampillai, T.; Allison, S.; Gupta, A. NICE guidelines for schizophrenia: Can art therapy be justifi ed? Correspondence 2016, 3, 1016-1017. [CrossRef]

147. Aladashvili, T. Art therapy for patients in acute psychotic episodes. Eur. Psychiatry 2017, 41, S377. [CrossRef]

148. Reid, S.; Hartzell, E. Art therapy with a group of dementia caregivers: Exploring wellbeing through social support and creative expression. Alzheimer's Dement. 2013, 9, P485. [CrossRef]

149. Shaw, C.; Washington, E.; Alavi, C.C.; Ray, A.; Carden, K.D.; Duncan, A.C.; Allen, R.S.; Aggarwal, N.T.; Potts, D.C. P2-520: Enhancing Dementia Care and Building Empathy through the Integration of Virtual Reality Technology and ART Therapy. Alzheimer's Dement. 2018, 14, P934-P935. [CrossRef]

150. Wang, Q.Y.; Li, D.W. Advances in art therapy for patients with dementia. Chin. Nurs. Res. 2016, 3, 105-108. [CrossRef]

151. Deygout, F.; Auburtin, G. Art therapy for elderly women diagnosed with Alzheimers: A positive person-centred approach increases ease in the care process. Ann. Médico-Psychol. Rev. Psychiatr. 2020, 178, 961-969. [CrossRef]

152. Ando, M.; Imamura, Y.; Kira, H.; Nagasaka, T. Feasibility and efficacy of art therapy for Japanese cancer patients: A pilot study. Arts Psychother. 2013, 40, 130-133. [CrossRef]

153. Geue, K.; Rieckhof, S.; Buttstaedt, M.; Singer, S. Do cancer patients with high levels of distress benefit more than less distressed patients from outpatient art therapy? Arts Psychother. 2017, 30, 1-7. [CrossRef]

154. Nainis, N.; Paice, J.A.; Ratner, J.; Wirth, J.H.; Lai, J.; Shott, S. Relieving symptoms in cancer: Innovative use of art therapy. J. Pain Symptom Manag. 2006, 31, 162-169. [CrossRef] [PubMed]

155. Rhondali, W.; Chirac, A.; Filbet, M. L'art-thérapie en soins palliatifs: Une étude qualitative. Médecine Palliat. Soins SupportAccompagnement-Éthique 2013, 12, 279-285. [CrossRef]

156. Öster, I.; Magnusson, E.; Thyme, K.E.; Lindh, J.; Åström, S. Art therapy for women with breast cancer:The therapeutic consequences of boundary strengthening. Arts Psychother. 2007, 34, 277-288. [CrossRef]

157. Öster, I.; Tavelin, B.; Thyme, K.E.; Magnusson, E.; Isaksson, U.; Lindh, J.; Åström, S. Art therapy during radiotherapy-A five-year follow-up study with women diagnosed with breast cancer. Arts Psychother. 2014, 41, 36-40. [CrossRef]

158. Öster, I.; Åström, S.; Lindh, J.; Magnusson, E. Women with breast cancer and gendered limits and boundaries: Art therapy as a 'safe space' for enacting alternative subject positions. Arts Psychother. 2009, 36, 29-38. [CrossRef]

159. Havsteen-Franklin, D.; Haeyen, S.; Grant, C.; Karkou, V. A thematic synthesis of therapeutic actions in arts therapies and their perceived effects in the treatment of people with a diagnosis of Cluster B personality disorder. Public Health 2021, 198, 245-251. [CrossRef]

160. Czamanski-Cohen, J.; Sarid, O.; Huss, E.; Ifergane, A.; Niego, L.; Cwikel, J. CB-ART-The use of a hybrid cognitive behavioral and art based protocol for treating pain and symptoms accompanying coping with chronic illness. Arts Psychother. 2014, 41, 320-328. [CrossRef]

161. Goujon, D.; Berenguer, L.; Romann, F. The new aspect of psychotherapy in our clinical psychiatric unit: The effort it took to make it work; and the first results. Eur. Psychiatry 2017, 41, s776. [CrossRef]

162. Regev, D.; Snir, S. Working with parents in parent-child art psychotherapy. Arts Psychother. 2014, 41, 511-518. [CrossRef]

163. Hawkes, E.; Heintz, H.; Vahia, I.V. Digitally enhanced art therapy and mindfulness in older adults. Am. J. Geriatr. Psychiatry 2020, 28, 495-496. [CrossRef]

164. Hawkes, E.; Heintz, H.; Forester, B.; Vahia, I. MINDFULNESS-BASED ART PSYCHOTHERAPY GROUP FOR OLDER ADULTS USING DIGITAL TOOLS. Am. J. Geriatr. Psychiatry 2019, 27, S172. [CrossRef]

165. Orkibi, H. The user-friendliness of drama: Implications for drama therapy and psychodrama admission and training. Arts Psychother. 2018, 59, 101-108. [CrossRef]

166. Azoulay, B.; Orkibi, H. The four-phase CBN Psychodrama Model: A manualized approach for practice and research. Arts Psychother. 2015, 42, 10-18. [CrossRef]

167. van den Broek, E.P.; Strijbos, N.; Vromen, J.; van Duursen, S.; Cousijn, J.; Bosschaert, L.; Zeegers, L.; van Zeeland, G.; Pouwels, S.; van den Berge, M.; et al. A pilot study of arts therapy techniques to evoke emotional states in forensic patients. Arts Psychother. 2021, 74, 101798. [CrossRef]

168. Register, D.M.; Hilliard, R.E. Using Orff-based techniques in children's bereavement groups: A cognitive-behavioral music therapy approach. Arts Psychother. 2008, 35, 162-170. [CrossRef]

169. Megranahan, K.; Lynskey, M.T. Do creative arts therapies reduce substance misuse? A systematic review. Arts Psychother. 2018, 57, 50-58. [CrossRef] 
170. Hakvoort, L.; Bogaerts, S. Theoretical foundations and workable assumptions for cognitive behavioral music therapy in forensic psychiatry. Arts Psychother. 2013, 40, 192-200. [CrossRef]

171. Fredenburg, H.A.; Silverman, M.J. Effects of cognitive-behavioral music therapy on fatigue in patients in a blood andmarrow transplantation unit: A mixed-method pilot study. Arts Psychother. 2014, 41, 433-444. [CrossRef]

172. Erfer, T.; Ziv, A. Moving toward cohesion: Group dance/movement therapy with children in psychiatry. Arts Psychother. 2006, 33, 238-246. [CrossRef]

173. Lee, H.J.; Jang, S.H.; Lee, S.Y.; Hwang, K.S. Effectiveness of dance/movement therapy on affect and psychotic symptoms in patients with schizophrenia. Arts Psychother. 2015, 45, 64-68. [CrossRef]

174. Bräuninger, I. The efficacy of dance movement therapy group on improvement of quality of life:A randomized controlled trial. Arts Psychother. 2012, 39, 296-303. [CrossRef]

175. Rainbow, T.H. Effects of dance movement therapy on Chinese cancer patients: A pilot study in Hong Kong. Arts Psychother. 2005, 32, 337-345.

176. Bojner-Horwitz, E.; Theorell, T.; Anderberg, U.M. Dance/movement therapy and changes in stress-related hormones: A study of fibromyalgia patients with video-interpretation. Arts Psychother. 2003, 30, 255-264. [CrossRef]

177. Blázquez, A.; Guillamó, E.; Javierre, C. Preliminary experience with dance movement therapy in patients with chronic fatigue syndrome. Arts Psychother. 2010, 37, 285-292. [CrossRef]

178. Bräuninger, I. Specific dance movement therapy interventions-Which are successful? An intervention and correlation study. Arts Psychother. 2014, 41, 445-457. [CrossRef]

179. Jerak, T.; Vidrih, A.; Žvelc, G. The experience of attunement and misattunement in dance movement therapy workshops. Arts Psychother. 2018, 60, 55-62. [CrossRef]

180. Hartwich, P.; Brandecker, R. Computer-based art therapy with inpatients: Acute and chronic schizophrenics and borderline cases. Arts Psychother. 1997, 24, 367-373. [CrossRef]

181. Kim, S.; Bae, J.; Lee, Y. A computer system to rate the color-related formal elements in art therapy assessment. Arts Psychother. 2007, 34, 223-237. [CrossRef]

182. Kim, S.; Kang, H.S.; Kim, K.E. Computer determination of placement in a drawing for art therapy assessments. Arts Psychother. 2008, 35, 49-59. [CrossRef]

183. Kim, S.; Kang, H.S.; Chung, S.; Hong, E. A statistical approach to comparing the effectiveness of several art therapy tools in estimating the level of a psychological state. Arts Psychother. 2012, 39, 397-403. [CrossRef]

184. Mattson, D.C. Standardizing the Formal Elements Art Therapy Scale (FEATS) rotation scale with computerized technology: A pilot study. Arts Psychother. 2011, 38, 120-124. [CrossRef]

185. Kim, S.; Han, J.; Kim, Y.H.; Oh, Y.J. A Computer Art Therapy System for Kinetic Family Drawing (CATS KFD). Arts Psychother. 2011, 38, 17-28. [CrossRef]

186. Kim, S.; Kang, H.S.; Kim, Y.H. A computer system for art therapy assessment of elements in structured mandala. Arts Psychother. 2009, 36, 19-28. [CrossRef]

187. Mattson, D.C. Issues in computerized art therapy assessment. Arts Psychother. 2010, 37, 328-334. [CrossRef]

188. Mattson, D.C. Usability assessment of a mobile app for art therapy. Arts Psychother. 2015, 43, 1-6. [CrossRef]

189. Collette, N.; Güell, E.; Fariñas, O.; Pascual, A. Art Therapy in a Palliative Care Unit: Symptom Relief and Perceived Helpfulness in Patients and Their Relatives. J. Pain Symptom Manag. 2021, 61, 103-111. [CrossRef] [PubMed]

190. Youngwerth, J.; Kutner, J.; Somes, L.; Jones, A.; Wibben, A. Integrating Creative Art Therapy with Palliative Care (QI743). J. Pain Symptom Manag. 2019, 57, 479-480. [CrossRef]

191. Wong, V.; Neo, P.S.H. An Integrative Approach: Dignity-Conserving Practice through Dyad Art Therapy for Hospice Patients and their Caregivers. J. Pain Symptom Manag. 2018, 56, e74-e75. [CrossRef]

192. Lee, R.; Wong, J.; Shoon, W.L.; Gandhi, M.; Lei, F.; Kua, E.H.; Rawtaer, I.; Mahendran, R. Art therapy for the prevention of cognitive decline. Arts Psychother. 2019, 64, 20-25. [CrossRef]

193. Israeli, R.; Regev, D.; Goldner, L. The meaning, challenges, and characteristics of art therapy for older Holocaust survivors. Arts Psychother. 2021, 74, 101783. [CrossRef]

194. Hass-Cohen, N.; Bokoch, R.; Goodman, K.; Conover, K.J. Art therapy drawing protocols for chronic pain: Quantitative results from a mixed method pilot study. Arts Psychother. 2021, 73, 101749. [CrossRef]

195. Hamamci, Z. Integrating psychodrama and cognitive behavioral therapy to treat moderate depression. Arts Psychother. 2006 33, 199-207. [CrossRef]

196. Roghanchi, M.; Mohamad, A.R.; Mey, S.C.; Momeni, K.M.; Golmohamadian, M. The effect of integrating rational emotive behavior therapy and art therapy on self-esteem and resilience. Arts Psychother. 2013, 40, 179-184. [CrossRef]

197. Chen, T.H.; Lu, R.B.; Chang, A.J.; Chu, D.M.; Chou, K.R. The evaluation of cognitive-behavioral group therapy on patient depression and self-esteem. Arch. Psychiatr. Nurs. 2006, 20, 3-11. [CrossRef]

198. Lorian, C.N.; Titov, N.; Grisham, J.R. Changes in risk-taking over the course of an internet-delivered cognitive behavioral therapy treatment for generalized anxiety disorder. J. Anxiety Disord. 2012, 26, 140-149. [CrossRef] [PubMed]

199. Lee, M.B. Dance Movement Therapy: A Creative Psychotherapeutic Approach. Arts Psychother. 2003, 30, 53-57. [CrossRef]

200. Ellis, R. Movement metaphor as mediator: A model for the dance/movement therapy process. Arts Psychother. 2001, 28, 181-190. [CrossRef] 
201. Meekums, B.; Vaverniece, I.; Majore-Dusele, I.; Rasnacs, O. Dance movement therapy for obese women with emotional eating: A controlled pilot study. Arts Psychother. 2012, 39, 126-133. [CrossRef]

202. Orr, P. Technology use in art therapy practice: 2004 and 2011 comparison. Arts Psychother. 2012, 39, 234-238. [CrossRef]

203. Orr, P.P. Distance supervision: Research, findings, and considerations for art therapy. Arts Psychother. 2010, 37, 106-111. [CrossRef] 